Revista de Estudios Histórico-Jurídicos

[Sección historia del derecho patrio]

XLI (Valparaíso, Chile, 2019)

[pp. 367-397]

\title{
LA EDIFICACIÓN. ANTECEDENTES HistóRICOS DE LOS ARTí́Culos 668 y 669 DEl Código Civil CHILENO
}

\author{
[Building works. Historical background of articles 668 and 669 of chile's Civil \\ Code] \\ María de los Ángeles Soza RieD* \\ Universidad de los Andes, Chile**
}

\begin{abstract}
RESUMEN
Desde épocas muy remotas los romanos se preguntaron qué sucedía cuando alguien construía un edificio con materiales ajenos en suelo propio, y cómo resolver el problema de la construcción levantada por un tercero en suelo ajeno. En ambos casos se aplicaba el antiquísimo principio romano enunciado como superficies solo cedit: el dueño del suelo se convierte en dueño del edificio, por accesión. En el primer supuesto, el dueño de los materiales - por la prohibición de origen decenviral- no puede separarlos mientras esté en pie la construcción; sí puede, en cambio, intentar una acción penal para exigir el doble del valor de los mismos (actio de tigno iuncto), acción que en el artículo 668 del Código Civil chileno queda sustituida por un derecho a pedir el simple valor de los materiales, y eventualmente a reclamar perjuicios. Este cambio es producto de la legislación justinianea, que habla de una pérdida del dominio de los materiales y de un derecho a ser indemnizado por el valor de los mismos. A nuestro modo de ver, la redacción del artículo se inspira en el proyecto de Código Civil español de García Goyena. En el segundo supuesto, el derecho romano
\end{abstract}

\begin{abstract}
During ancient times the romans contemplated how to resolve two kinds of problems. First, if a person builds over his land but with other person's materials; second, if a person builds in the land of another one. In both cases the landowner becomes the owner of the building through accession as a consequence of an ancient Roman law principle: superficies solo cedit (what is adhered to the land is considered to be an accession to it). In the first case, the owner of the materials was not permitted to separate them from the construction based on an old prohibition. However may get, through an action, the double value of them. According to modern Civilian law, this action is substituted, in the article 668 of our Civilian Chilean Code, by a lawsuit for compensatory damages. This change is due to the Justinian's legislation, which stablishes that in this case the owner loses the material's property, but has the right to claim for the value of them. In our mind, the wording of this article is inspired by the project of Spanish Civil Code written by García Goyena. In the second situation, the Roman
\end{abstract}

* Licenciada en Ciencias Jurídicas y Sociales, Universidad de Chile, Abogado, Doctora en Derecho, Universidad de Santiago de Compostela, España, Profesora de Derecho Romano, Universidad de los Andes, Chile, Mons. Álvaro del Portilllo 12.455, Las Condes, Facultad de Derecho, Edificio El Reloj. Correo electrónico: mdsoza@miuandes.cl

** El presente trabajo es un producto del proyecto Fondecyt Regular 2015, 1150634. Varias de las conclusiones de este trabajo se encuentran en otro artículo de la misma autora: $L a$ edificación y la adquisición del dominio del edificio, publicado en Estudios de derecho civil V, Jornadas Nacionales de derecho civil, (Concepción, Abeledo Perrot, LegalPublishing, 2009), pp. 165-179. 
se plantea un problema posesorio que se soluciona otorgando al dueño del suelo una acción reivindicatoria para recuperar la posesión del terreno. Si resulta vencedor, proceden las restituciones recíprocas que establece el derecho. El artículo 669 de nuestro Código resuelve el problema de un modo similar, aunque contempla una alternativa que no aparecía en el derecho romano. Es muy probable que esta novedad provenga del artículo 404 del proyecto de Código Civil español de 1851, cuyo texto plantea esta misma opción. La solución del artículo, en verdad ingeniosa, es de algún modo equivalente a la presentada en el derecho romano por Celso, para el caso de ser pobre el propietario del suelo. El método de investigación que predomina en este trabajo es el histórico, que ha permitido descubrir, en las normas actuales que desarrollamos, la importante huella de las soluciones ideadas en el derecho romano. Se ha utilizado también el método exegético, por una parte, para el análisis de algunos textos romanos cuya interpretación ha sido más problemática a la luz de la bibliografía trabajada, y, por otra, para el estudio de las normas actuales. En este segundo sentido, la exégesis normativa ha quedado plenamente iluminada por la realidad de estas figuras en el ámbito del derecho romano.

Palabras Clave

Suelo - tignum iunctum - construcción - materiales - accesión. law resolves the possessory problem by giving the landowner the action to recover possession. Nowadays -in the article 669 of the Civilian Chilean Code-, the question is decided in a similar way. In fact, if the landowner wants to recover the possession, he must pay the improvements made in the land. Nevertheless, this article offers an option that never appeared in Roman law. Probably this option is connected with article 404 of the project of Spanish Civil Code written by García Goyena, which presents this alternative. The article provides an ingenious solution that is equivalent to Celso's answer in the case of a poor proprietor of the land. The historical method used in this research has permitted us to discover the marks of roman's solutions in the current legislation. We have used also the exegetic method; in one sense as a way to analyze the most difficult texts of Roman law related to this topic; in the other, in order to examine the current rules with respect to this issue. In this second sense, the legislative's interpretation has been enlightened by the solutions created in Roman law.

ReCibido el 16 de noviembre de 2018 y ACEPTADO el 18 de junio de 2019

\section{INTRODUCCIÓN}

La doctrina romanística, para abordar los supuestos que nos ocupan -construcción de un edificio en suelo propio con materiales ajenos y construcción de un edificio en suelo ajeno- suele hablar de inaedificatio, que se traduce al castellano como edificación ${ }^{1}$. El término adquiere, de este modo, más allá del sentido natural

${ }^{1}$ El verbo aedifico en latín es equivalente a inaedifico y viene de aedes (templo, casa). El sustantivo aedificatio significa lo que su sentido natural y obvio sugiere: en cuanto acción y efecto de edificar, es sinónimo de edificio, y en este sentido es equivalente a aedificium. Vid. Diccionario Latino-Español, BlÁNQUeZ, Agustín (5ª ed., Barcelona, editorial Ramón Sopena, 1982). 
y obvio (edificio o construcción), el técnico al que ya nos referimos. Las figuras que comentamos, sin embargo, aunque se encuentran tratadas fundamentalmente en dos partes del Digesto (título I, del libro 41, dedicado a la adquisición del dominio de las cosas, y título III del libro 47 -sede de delitos privados-, referido a la acción del madero empotrado: actio de tigno iuncto) carecen de un nombre propio.

En el trasfondo de esta materia está el principio superficies solo cedit, en virtud del cual, todo lo que accede al suelo se hace del dueño del suelo. Tal principio se aplica con todo vigor, tanto en caso de que exista un contrato de construcción ${ }^{2}$, como en los supuestos en que la relación contractual es inexistente (que trataremos en este trabajo). Los juristas romanos pensaban que es una regla o precepto que arranca de la naturaleza misma de las cosas, y es eso precisamente lo que le da su consistencia.

Después de aclarar estos puntos preliminares, quisiéramos subrayar que este trabajo pretende ofrecer una interpretación de los dos artículos del Código Civil que abordan los supuestos de construcción en suelo propio con materiales ajenos y de edificación en suelo ajeno, a la luz del tratamiento de estos problemas en el ámbito del derecho romano ${ }^{3}$. Como podremos apreciar $-\mathrm{y}$ ese es el sentido de la parte romanística de este trabajo- ambos supuestos son analizados en la jurisprudencia desde la época más antigua del derecho romano. El tratamiento jurisprudencial clásico y luego el justinianeo, nos permiten entender el sentido de las normas que Andrés Bello plasma en los artículos $668^{4}$ y $669^{5}$ del Código Civil.

${ }^{2}$ A propósito de esta cuestión, es interesante leer lo que afirma SAN MARTín, Lilian, Algunas consideraciones sobre el contrato para la confección de obra material. Problemas derivados de su configuración típica, en Estudios de derecho civil X, y LA MISMA, Contrato para la confección de obra material. Naturaleza jurídica y otros problemas dogmáticos, en Revista de Derecho Universidad Católica del Norte, 23 (2016). A su juicio, cuando alguien contrata la construcción de un edificio en su terreno debe hablarse siempre de arrendamiento (de obra), pues el suelo es la materia principal. Fundamenta esta afirmación en las fuentes históricas que sirven de antecedente al art. 1996: D. 18, 1, 20 que recoge la opinión de Sabino, y el $\$ 394$ del Tratado de la locación y conducción de Pothier. Según la autora, esta solución conecta también con las normas del Código Civil que regulan la accesión.

${ }^{3}$ Aunque en derecho romano los casos de inaedificatio se planteaban junto al supuesto del que plantó o sembró en suelo propio vegetales o semillas ajenas, o del tercero que sembró o plantó en suelo ajeno, nos centraremos en los casos de edificación, que presentan más interés y complejidad.

${ }^{4}$ Art. 668 del Código Civil chileno: [inc. $1^{\circ}$ ] Si se edifica con materiales ajenos en suelo propio, el dueño del suelo se hará dueño de los materiales por el hecho de incorporarlos en la construcción; pero estará obligado a pagar al dueño de los materiales su justo precio, u otro tanto de la misma naturaleza, calidad y aptitud. [inc. 20] Si por su parte no hubo justa causa de error, será obligado al resarcimiento de perjuicios, y si ha procedido a sabiendas, quedará también sujeto a la acción criminal competente; pero si el dueño de los materiales tuvo conocimiento del uso que se hacía de ellos, sólo habrá lugar a la disposición del inciso anterior. [inc. $3^{\circ}$ ] La misma regla se aplica al que planta o siembra en suelo propio vegetales o semillas ajenas. [inc. $4^{\circ}$ ] Mientras los materiales no están incorporados en la construcción o los vegetales arraigados en el suelo, podrá reclamarlos el dueño.

${ }^{5}$ Artículo 669 del Código Civil chileno: [inc. $1^{\text {o] }}$ El dueño del terreno en que otra persona, sin su conocimiento, hubiere edificado, plantado o sembrado, tendrá el derecho de hacer suyo el edificio, plantación o sementera, mediante las indemnizaciones prescritas a favor de los poseedores de buena o mala fe en el título De la reivindicación, o de obligar al que edificó o plantó a pagarle el justo precio 
El estudio de los antecedentes históricos de estas normas es imprescindible, por cuanto no contamos con referencias explícitas que permitan conocer los fundamentos en que se habría inspirado Bello en la redacción de ambos artícu$\operatorname{los}^{6}$. En efecto, carecemos de actas de las comisiones que prepararon la redacción definitiva del Código Civil chileno. Por otra parte, apenas existen notas en los proyectos que antecedieron a la versión definitiva del Código, que permitan conocer las fuentes inspiradoras de Andrés Bello. Sin embargo, gracias al estudio de las fuentes romanas y a la bibliografía que las analiza en profundidad, podremos aventurar los motivos que tuvo Bello para plasmar las decisiones de la forma en que las leemos en dichos artículos.

El tema que nos ocupa se inscribe en lo que nuestro Código denomina accesión de cosas muebles a inmuebles y que se regula en solo dos artículos: los ya mencionados 668 y 669, inscritos bajo el epígrafe De la accesión de las cosas muebles a inmuebles. La doctrina del Derecho Civil califica ambos supuestos como formas de accesión industrial, de acuerdo con la distinción entre accesiones naturales, industriales y mixtas, que Bello recoge en sus Instituciones de Derecho Romano ${ }^{7}$. La distinción se hallaba ya presente en el anteproyecto de Código Civil español de García Goyena ${ }^{8}$, que en el artículo 401 dice: "Lo edificado, plantado y sembrado

del terreno con los intereses legales por todo el tiempo que lo haya tenido en su poder, y al que sembró a pagarle la renta y a indemnizarle los perjuicios. [inc. $2^{\circ}$ ] Si se ha edificado, plantado o sembrado a ciencia y paciencia del dueño del terreno, será éste obligado, para recobrarlo, a pagar el valor del edificio, plantación o sementera.

${ }^{6}$ Así lo dice Salinas, Carlos, Notas en torno a las actas de los proyectos del Código Civil chileno, en rdpucv.cl/index.php/rderecho/article/viewFile/2/2, consultado el 10.VI.19, pp. 31 a 41, ver especialmente lo señalado en p. 39 y 41 in fine. El autor afirma que solo se han encontrado algunas actas - de escaso contenido sustantivo-, en relación con el trabajo de la Comisión de Legislación (relativa a los primeros proyectos de Código), lo cual permite pensar que también las hubo en la Comisión Revisora (que analizó el Proyecto de 1853). Esta circunstancia nos obliga a conjeturar acerca de las posibles fuentes antiguas en las que se habría inspirado el legislador para adoptar la redacción definitiva de estas normas.

${ }^{7}$ BeLlo, Andrés, Instituciones de derecho romano (Santiago de Chile, Libr. Central de Augusto Raymond, Impr. Nacional, 1871). Dice en p. 48: "La accesion es de tres especies, natural, industrial i mista”. Después de describir supuestos de accesión natural como el parto de los animales y las producciones espontáneas del suelo, pasa a explicar, en p. 49, que "La accesion industrial es de varias especies, que se llaman adjuncion, especificacion i conmistion”. Describe, a continuación, diversos casos de adjunción como, por ejemplo, el engaste o la soldadura, y también, en p. 50, la edificación: "El dueño de la materia con que otro edifica en suelo propio, conserva el dominio de ella, pero no puede vindicarla, ni tiene accion ad exhibendum por la lei de las XII Tablas, que probibe se obligue al dueño del suelo a destruir el edificio, sino solo a pagar el duplo por la accion de tigno iuncto. Destruido el edificio, puede el dueño de los materiales, si no ha recibido el duplo, vindicarlos o intentar la accion ad exhibendum. Si se ha edificado en suelo ajeno, el dueño de la materia, que edificó a sabiendas de no pertenecerle el suelo, pierde la propiedad de ella: de manera que ni aun destruido el edificio, puede vindicar los materiales. Mas el que edificó i está poseyendo de buena fe, puede repeler al dueño del suelo por la escepcion doli mali, mientras no le abone el precio de los materiales i los demás gastos; i si dejó de poseer, destruido el edificio, puede vindicar los materiales. Si no posee, i el edificio está en pié, el edificador no tiene accion alguna".

${ }^{8}$ García Goyena, Florencio, Concordancias, motivos y comentarios del Código Civil Español (Madrid, Imprenta de la Sociedad Tipográfico-Editorial, 1852), I, cap. IV, Del derecho de accesión respecto de los bienes inmuebles. 
en terreno ó fincas agenas, y las mejoras ó reparaciones hechas en ello, pertenecen al dueño de los mismos, con sujecion á lo que se dispone en los artículos siguientes". Para el autor, en ambos casos estaríamos hablando de un subtipo de accesión industrial que recibe el nombre de adjunción.

\section{ANÁLISIS DEL PRIMER SUPUESTO}

LA CONSTRUCCIÓN DE UN EDIFICIO EN SUELO PROPIO CON MATERIALES AJENOS

\section{La cuestión de la "actio de tigno iuncto"}

De acuerdo con la afirmación hecha en la presentación del trabajo, en virtud del principio superficies solo cedit, el dueño del suelo se hace propietario del edificio, en todo caso, y a pesar de haber construido con materiales ajenos?

Veamos ahora lo que sucede con el dueño de los materiales. ¿Pierde el dominio de estos al quedar incorporados al edificio? Antes de entrar de lleno en el asunto, parece necesario recordar que el edificio es considerado por los juristas como una cosa compuesta ${ }^{10}$, y al no poder subsistir de manera independiente del suelo, accede al propietario del terreno de modo unitario e inseparable.

Cuando el edificio ya está en pie, teóricamente sería procedente-como ocurre en otros casos de accesión- que el propietario de los materiales intente la actio

\footnotetext{
${ }^{9}$ No ahondaremos en este principio, sobre cuyo origen antiguo y subsistencia durante muchos siglos de la historia del derecho romano no hay duda en la doctrina. Según, ZAERA, Ana, Superficies solo cedit, en Anuario da Facultade de Dereito da Universidade da Coruña, 12, p. 1010, el principio proviene de los mores maiorum, que los juristas asocian al ius naturale (así, por ejemplo, Gayo, Paulo y Ulpiano). Sobre los enunciados de este principio pueden verse, por ejemplo, Gayo, Inst, 2,73; D.9,2,50; D.41,1,7,10; D.43,18,2. La prevalencia de la tierra y de la actividad económica que se genera en torno a ella, explica que este principio sea considerado como inderogable e indisponible para las partes: ZAERA, Ana, Superficies cit. (en esta misma nota, supra), p. 1011. En virtud de esta regla, no se admite la propiedad separada del suelo y del edificio que se encuentra sobre él, lo que parece explicar adecuadamente por qué lo construido en la superficie accede siempre al dueño del suelo. Según señala Biondi, Biondo, Istituzioni di Diritto Romano (reimp. de la $4^{\mathrm{a}}$ ed., Milán, Giuffrè, 1972), p. 244, la antigua interpretación de la ley decenviral relacionó este principio con la estructura del dominio, que atrae todo lo que se incorpora a la cosa. Señala que Wenger, Superficies solo cedit, en Philologus, 88 (1933), p. 254 ss. [no hemos podido encontrar esta referencia para la cita directa] piensa, en cambio, que deriva de una ley griega. En virtud de la misma regla, tampoco se admite la llamada "propiedad horizontal" sobre los pisos de una insula. Sobre la evolución de este principio en tiempos de Justiniano, puede verse, ZAERA, Ana, La propiedad superficiaria en el derecho romano justinianeo, en $R I D A$., 51 (2004). La autora, en p. 378, se cuestiona si en esta época tardía se considera ya realmente el edificio como una unidad. $\mathrm{Y}$ añade que el derecho romano posclásico se vio afectado en esta materia por la vulgarización jurídica, sobre todo si se tiene en cuenta que en otros derechos de la antigüedad este principio civil no era conocido.

${ }^{10}$ Lo pone de manifiesto Biondi, Biondo, Istituzioni cit. (n. 9), p. 245. Lo dice también Iglesias, Juan, Derecho romano (17a ed., Barcelona, Ariel, 2008), p. 70; la propiedad sobre el todo no implica propiedad sobre los materiales, que permanece de modo latente mientras dura la conjunción. En relación con este punto, VOCI, Pasquale, Istituzioni di diritto romano (Milán, Giuffrè, 1996), p. 276, n. 12, señala que el propietario de los materiales no ha de temer la usucapión por parte del dueño del edificio, ya que éste posee el edificio como un todo (cosa compuesta), y no los materiales.
} 
ad exhibendum que le permite separar los materiales y luego reivindicarlos ${ }^{11}$. Sin embargo, en virtud de una antigua prohibición de origen decenviral, que protege intereses generales de naturaleza urbanística y agrícola, esta posibilidad no existe ${ }^{12}$.

La regla que impone esta prohibición aparece en el principio de un fragmento de Ulpiano ${ }^{13}$ (D. 47,3,1pr. Ulp. 37 ad ed.), que es explícito en cuanto a la motivación que habría tenido esta disposición legal: la de evitar la destrucción de los edificios o de las viñas ${ }^{14}$. De Marini ${ }^{15}$, acerca de esta regla y de la asociación entre la viga que soporta el edificio y los palos que sostienen la viña, hace una interesante reflexión de carácter histórico. Los descubrimientos arqueológicos en torno al Palatino demuestran que en el siglo VIII a.C. las casas -habitualmente de madera- eran sostenidas por una viga central. En la viticultura, en el mismo siglo, prevalece la usanza etrusca, en que las vides se apoyan y estructuran con palos de madera.

${ }^{11}$ Se trata de la solución que aceptan en general los juristas cuando se ha producido una especificación de mala fe.

${ }^{12}$ IGLESIAS, Juan, cit. (n. 10), p. 170, comenta que la misma jurisprudencia clásica y luego el derecho justinianeo fueron restringiendo el alcance de esta norma decenviral. Según veremos más adelante, el derecho y, particularmente una de las escuelas de juristas, permitió el ius tollendi cuando la construcción aún esté en pie, siempre que no se produzca menoscabo para el edificio (D. 6,1,37; D. 6,1,25; C.3,32,5).

${ }^{13}$ En la edición y traducción de Ruiz Castellanos, Antonio, Ley de la Doce Tablas (Madrid, Ediciones Clásicas, 1992), se aduce este fragmento para señalar el contenido de la tabla IV. 8 a) Tignum iunctum aedibus vineave concapitum ne solvito. "Las vigas empotradas en los edificios o los rodrigones enzarzados con las vides, una vez formen una unidad, no se podrán separar". El editor señala que el contenido de la tabla IV. 8 b) de la Ley es recogido del $\$ 1$ de ese fragmento. En la edición y traducción de Rascón, César y García, José María, Ley de las Doce Tablas (Madrid, Tecnos, 2011), este texto figura como Tabla VI, 9.

${ }^{14}$ Lex duodecim tabularum neque solvere permittit tignum furtivum aedibus vel vineis iunctum neque vindicare (quod providenter lex effecit ne vel aedificia sub hoc praetextu diruantur vel vinearum cultura hoc praetextu diruantur vel vinearum cultura turbetur) sed in eum, qui convictus est iunxisse, in duplum dat actionem. La existencia del precepto parece tomada de un pasaje de Festo que dice lo siguiente: Tignum non solum in aedifciis, quo utuntur, appelatur, sed etiam in vineis, ut est in XII: "Tignum iunctum aedibus vineaeve et concapit ne solvito". Conviene revisar, en relación con este pasaje, la reconstrucción de WaTSON, Alan, Tignum Iunctum, the XII Tables and a Lost Word, en RIDA., 21 (1974), pp. 337-342, que propone el sustantivo concaput en vez de la forma verbal concapit. Para MusumeCI, Francesco, Inaedificatio (Milano, Giuffrè, 1988), p.14 ss., en cambio, el texto decía concapit en vez de concapitum. A su juicio, el concapere significa, en el lenguaje decenviral, la operación de unir, y el uso de los tiempos verbales le hace pensar que la prohibición se refiere siempre al dueño de los materiales (al dominus tigni), sea que la incorporación la haya hecho él mismo, sea que la haya hecho un tercero. De esto deduce que la prohibición no afecta al dueño del suelo, quien puede destruir la edificación, o provocar al tercero a que lo haga, afirmación que apoya en algunos textos del Digesto. No podremos abundar en esta explicación, que es de todas formas, interesante. En opinión de Marrone, Matteo, Tignum iunctum e "Inaedificatio", en Labeo, 37 (1991) pp. 382-387, esta conclusión es un importante acierto de Musumeci. Señala, en todo caso, siguiendo a Riccobono, Salvatore, Studi critici sulle fonti del diritto romano, en BIDR., 8 (1895), p. 242, que las razones publicísticas en que se apoya esta prohibición hacen más probable que ella -al menos en la época más arcaica- se dirija tanto al dueño de los materiales (dominus tigni) como al dueño del suelo (dominus soli).

${ }^{15}$ De Marini, Franca, Recensión a Quadrato, Tignum Iunctum, en Labeo, 15 (1969), pp. 380-381. 
Pero la prohibición fue interpretada de un modo amplio: según figura en el $\$ 1$ del mismo pasaje, incluye otro tipo de materiales incorporados a una construcción ${ }^{16}$. Según Riccobono ${ }^{17}$, la interpretación más amplia de la prohibición por parte de los juristas pontífices se habría debido al cambio en las condiciones edilicias de Roma, a consecuencia del incendio de los galos: las construcciones más sólidas habrían sustituido a las antiguas de madera.

El dueño de los materiales, pues, no puede separarlos de la construcción que está en pie. Sin embargo, como contrapartida de esta prohibición, en la ley de las XII Tablas aparece una acción para dicho propietario ${ }^{18}$, que le permite exigir el doble del valor de los materiales (acción de tigno iuncto) ${ }^{19}$.

Una cuestión de la mayor relevancia es la de definir qué tipo de acción sería esta que concede la disposición decenviral. La mayoría de los autores coincide en que se trata claramente de una acción penal, cuya pena asciende al doble del valor de los materiales. En relación con el carácter penal de esta acción, Biondi ${ }^{20}$ señala que por derecho civil no existe ningún tipo de indemnización por los materiales mientras el edificio está en pie. Solo procede, en caso de hurto de materiales, la actio de tigno iuncto ${ }^{21}$.

${ }^{16}$ Tigni autem appellatione continetur omnis materia, ex qua aedificium constet, vineaeque necessaria. unde quidam aiunt tegulam quoque et lapidem et testam ceteraque, si qua aedificiis sunt utilia (tigna enim a tegendo dicta sunt), hoc amplius et calcem et harenam tignorum appellatione contineri. sed et in vineis tigni appellatione omnia vineis necessaria continentur, ut puta perticae pedamenta. Algo casi idéntico dice Gayo en relación con el vocablo tignum (viga o madero): D. 50,16,62-Gai. 26 ad ed. prov.: 'tigni' appellatione in lege duodecim tabularum omne genus materiae, ex qua aedificia constant, significatur. "El vocablo "tignum"-viga o madero- de que se habla en la Ley de las XII Tablas, alude también a toda clase de materia de que el edificio se compone".

${ }^{17}$ Según Riccobono, cit. (n. 14), p. 9.

${ }^{18}$ GIRARD, Paul, Manuel elementaire de droit romain (8a ed., París, 1929), pp. 355 ss. Plantea esta acción como una compensación frente a la mencionada prohibición.

${ }^{19} \mathrm{Un}$ buen resumen de las dos posiciones doctrinarias en torno a los textos relacionados con el tignum iunctum puede encontrarse en GUARINO, Antonio, Diritto privato romano (11 ${ }^{\text {a }}$ ed., Napoli, Jovene, 1997), p. 667. El autor, en nota al pie (\$58.5.3), recuerda que uno de ellos, Monier (Le tignum iunctum, 1922), acusa la existencia de numerosas interpolaciones justinianeas en este grupo de textos, mientras que Melillo (Tignum Iunctum, 1964) y otros autores posteriores, se inclinan por la autenticidad de dichos pasajes.

${ }^{20}$ Biondi, Biondo, cit. (n. 9), p. 245.

${ }^{21}$ Los textos más relevantes en que se apoya la existencia de esta antigua prohibición, así como de la actio de tigno iuncto, son: D. 47,3,1 pr. Ulp. 37 ad ed., ya transcrito, y el fragmento 2 del mismo jurista, los únicos del título III del libro 47 del Digesto, cuya rúbrica es precisamente De tigno iuncto; D. 6,1,23,6- Paul. 21 ad ed. Tignum alienum aedibus iunctum nec vindicari potest propter legem duodecim tabularum, nec eo nomine ad exhibendum agi nisi adversus eum, qui sciens alienum iunxit aedibus: sed est actio antiqua de tigno iuncto, quae in duplum ex lege duodecim tabularum descendit. y D. 41,1,7,10- Gai. 2 rer. cott. Cum in suo loco aliquis aliena materia aedificaverit, ipse dominus intellegitur aedificii, quia omne quod inaedificatur solo cedit. nec tamen ideo is qui materiae dominus fuit desiit eius dominus esse: sed tantis per neque vindicare eam potest neque ad exhibendum de ea agere propter legem duodecim tabularum, qua cavetur, ne quis tignum alienum aedibus suis iunctum eximere cogatur, sed duplum pro eo praestet. appellatione autem tigni omnes materiae significantur, ex quibus aedificia funt. ergo si aliqua ex causa dirutum sit aedificium, poterit materiae dominus nunc eam vindicare et ad exhibendum agere. Otros hablan de la extensión de la expresión tignum a otro tipo de materiales. Son, los ya mencionados, D. 
Según señala Volterra ${ }^{22}$, la naturaleza de la acción de tigno iuncto es uno de los puntos espinosos de la doctrina romanística. Mientras un grupo de autores afirma que existe una conexión esencial entre esta acción y el hurto, otro afirma que la acción es procedente también cuando el que construyó no sabía que se trataba de materiales ajenos ${ }^{23}$.

En la segunda mitad del siglo pasado aparecen algunos autores que tienden a pensar que esta acción no distingue según si los tigna (materiales), son simplemente ajenos o han sido hurtados. En ambos casos procedería la acción penal de tigno iuncto por el doble del valor de los materiales. Así, Melillo, Musumeci y Quadrato.

Melillo $^{24}$, afirma que la acción, en la época más antigua, no distingue entre apropiación dolosa o no de los materiales ajenos incorporados a la construcción. En ambos casos procede una acción penal por el doble. En su intento de contrarrestar la exagerada crítica interpolacionística de la primera mitad del siglo XX, interpreta los textos referidos a la materia intentando descubrir en ellos la evolución histórica del pensamiento jurídico. A su juicio, en la época arcaica la acción habría tenido indiscutiblemente una naturaleza penal, sin embargo, no habría exigido necesariamente el furtum de los materiales. Lo explica amparándose en la convicción de un sector de la doctrina que afirma que en la época antigua se habría usado más bien un sistema de responsabilidad objetiva. Señala que ya en la época de Neracio, y en especial en la era de los Severos ${ }^{25}$, se produce una sistematización del hurto, y el elemento sicológico se transforma en un factor determinante para la calificación jurídica del ilícito. De este modo, desde la época tardo clásica (y por supuesto en el derecho posclásico y justinianeo) la figura del tignum iunctum se desdobla y admite dos supuestos distintos: la apropiación de buena y la de mala fe. Esta figura (apropiación de materiales ajenos) se aproxima al delito de hurto, pero se distingue de éste por cuanto se elimina la acción reivindicatoria como cumulativa. De este modo, según señala el autor, se trataría de una acción mixta, que puede funcionar como reipersecutoria o como penal, según haya sido la disposición sicológica del constructor.

La tesis de Melillo tiene el mérito de analizar los textos desde una perspectiva histórica y de salvar la autenticidad de muchos pasajes cuya crítica pudo haber sido excesiva. Sin embargo, ha sido blanco de importantes objeciones por parte

47,3,1,1-Ulp. 37 ad ed. y D. 50,16,62-Gai. 26 ad ed. prov.; D. 10,4,7 pr.-Ulp. 24 ad ed. y la parte final del ya señalado D. 41,1,7,10-Gai. 2 rer. cott.

${ }^{22}$ VOLTERRA, Eduardo, Instituciones de derecho privado romano (trad. cast., Madrid, Civitas, 1986), pp. 336-338.

${ }^{23}$ Pampaloni, Muzio, Studi sopra il delitto di furto, en BIDR., 21 (1909), p. 211, además de resaltar la idea de que esta acción no puede sino reprimir el furtum, sostiene que probablemente ella procede por el doble en todos los casos en que se trata de materiales ajenos (tignum alienum), y por el cuádruplo cuando dichos materiales han sido hurtados (tignum furtivum). Reconoce que la relación de la actio de tigno iuncto con el furtum no es en el derecho clásico un tema definido. Esta opinión es atacada por KASER, Max, Typisierter "dolus" im altrömischen Recht, en BIDR, 65 (1962), p. 92, n. 45; le parece no suficientemente fundamentada.

${ }^{24}$ Melillo, Generoso, Tignum Iunctum (Napoli, Giuffrè, 1964).

${ }^{25}$ Ibíd., cap. IV, pp. 131 ss. 
de autores connotados. Así, por ejemplo, $\operatorname{Kaser}^{26}$, Medicus $^{27}$, Lemosse ${ }^{28}$, MayerMaly ${ }^{29}$, y Hincker ${ }^{30}$.

Un pensamiento similar a Melillo presenta Musumeci ${ }^{31}$ : en la época decenviral se habría usado la actio de tigno iuncto de modo indiferenciado, tanto para casos de mera ajenidad de los materiales como para hurto de los mismos ${ }^{32}$. A pesar de

${ }^{26}$ Kaser, Max, Recensión a Melillo, Tignum Iunctum, en Labeo, 12 (1966), pp. 104 ss., que, entre otras cosas (pp. 108-109), critica la categoría de acción mixta que Melillo atribuye a la actio de tigno iuncto.

${ }^{27}$ Medicus, Dieter, Recensión a Melillo, Tignum Iunctum, en SZZ., 97 (1967), pp. 476481. En un sentido similar, y apoyándose en el pensamiento de Kaser, señala (p. 478) que la mención clarísima de las fuentes en el sentido de una condena al duplum, hace que esta acción no pueda ser sino penal.

${ }^{28}$ Lemosse, Maxime, Recensión a Melillo, Tignum Iunctum, en RHD., (1966), pp. 89-90. También critica al autor, que, a pesar de reconocer la sanción penal de la actio de tigno iuncto, admite su colocación dentro de la categoría de acciones mixtas cuyo origen se encontraría en la época clásica. Tampoco le parece convincente la afirmación de que el carácter subjetivo de la represión penal se asocie históricamente a la época del Bajo Imperio.

${ }^{29}$ Mayer-Maly, Theodor, Recensión a Melillo, Tignum Iunctum, en SDHI., 33 (1967), pp. $433-438$.

${ }^{30}$ Hincker, Hannes, Tignum Iunctum, en SZZ., 121 (1991), pp. 94-122, que defiende de modo rotundo el carácter penal de esta acción.

${ }^{31}$ Musumeci, Francesco, Vicenda storica del "Tignum Iunctum", en BIDR., 89 (1978) p. 220 ss. El detalle de su pensamiento y el acucioso análisis de los textos referidos a este tema puede encontrarse en Musumeci, Francesco, Inaedificatio, cit. (n. 14). En pp. 107 ss., sobre la base de la exégesis de D. 24,1,63, que contendría una interpolación justinianea, intenta demostrar que en época clásica la actio de tigno iuncto no es procedente exclusivamente en casos de furtum de los materiales. Lo mismo afirma respecto de D. 6,1,23,6. Una cuestión compleja es la interpretación de D. 46,3,98,8-Paul 15 Quaest. sobre el que trabajan Melillo, Musumeci y Quadrato. El pasaje, en su parte final, reproduce la prohibición de separar los materiales de la ley decenviral, pero introduce, para el tiempo intermedio -interim-una posibilidad de pagar un precio. Melillo, Generoso, cit. (n. 24), p. 49 s. imagina que se trata de una actio ex stipulatu contra aquel que hubiese prometido el pago de los materiales. Quadrato, Tignum Iunctum ne solvito (Bari, Ari Grafique Laterza, 1967), citado por PASQUINO, Paola, Rimedi pretori in alcuni casi di accessione, en TSDP., 4 (2011), p. 93 n. 113 [no hemos podido citar directamente el libro], en cambio, apoya su explicación en el sistema procesal de la época clásica. En virtud de la condemnatio pecuniaria de la acción -en este caso reivindicatoria-, el pretium no sería otra cosa que el valor en dinero de la condena de la mencionada acción. Musumeci, en Vicenda strorica, cit. (en esta misma nota, supra), pp. 215 ss. critica la opinión de Quadrato, por lo que se refiere a la procedencia de la acción reivindicatoria cuando el edificio aún está en pie. Si el constructor hace uso de la facultad que le concede la cláusula arbitraria para evitar el pago de la condena (pretium), tendría que destruir el edificio para restituir los referidos materiales, lo que va en contra de la prescripción decenviral que conocemos (más tarde, en la obra de 1988 el autor cambia de opinión y afirma que la prohibición decenviral solo obliga al dueño de los materiales, pero no abundaremos aquí en esa argumentación). Por otra parte, el mismo Musumeci, Francesco, Inaedificatio, cit. (n. 14), pp. 71 ss. piensa que aquel pretium se refiere a una acción indemnizatoria que sería acumulable con la actio de tigno iuncto, de carácter penal, y sería procedente tanto en casos de tignum alienum como de tignum furtivum. Dicha acción indemnizatoria no sería acumulable, en cambio, con la acción reivindicatoria que se intenta cuando el edificio pierda su integridad.

${ }^{32}$ BuCKLAnd, William, A Manual of Roman Private Law (Cambridge, University Press, 2011), $\$ 53$, pp. 142 ss. parece aproximarse a esta posición. A su juicio, si el constructor robó 
esta aseveración, defiende de manera absoluta el carácter penal de esta acción, que castiga al que usó estos materiales al pago del doble de su valor. Y dada su naturaleza penal, le parece que ella es compatible con el ejercicio de la acción reivindicatoria cuando se produzca la desintegración del edificio.

La explicación de algunos de estos autores, que hace procedente la actio de tigno iuncto incluso cuando no hay hurto de materiales resulta, a mi modo de ver, poco convincente. La afirmación descansa en una doctrina bastante difundida que afirma que en la época más antigua predominaba un sistema de responsabilidad objetiva. Dicha doctrina ha sido cuestionada en materia de delitos privados, particularmente en relación con la iniuria o el furtum de la época arcaica. Por lo que se cree, también en esta época del derecho romano la consideración subjetiva, la disposición sicológica del autor del ilícito, era relevante ${ }^{33}$.

Seguimos, pues, la otra corriente doctrinal, que afirma la procedencia de la actio de tigno iuncto solo en casos de tignum furtivum. Lo afirma con mucha firmeza, Kaser $^{34}$, para quien la expresión tignum furtivum de D. 47,13,1 pr. es determinante. A su juicio, la colocación edictal de esta acción, en el título "De furtis", inmediatamente detrás de la actio furti nec manifesti hace esta afirmación aún más evidente; a lo que se suma la condena al doble del valor de los materiales y la compatibilidad de la acción con la posterior reivindicatoria. También lo dice Talamanca ${ }^{35}$ : esta acción no sería más que una aplicación particular de la actio furti, que, como ella, supone una actitud dolosa en el autor del delito. No consigue encontrar la razón por la que se conceda una actio de tigno iuncto autónoma o distinta de la actio furti ${ }^{36}$. Agrega, por otra parte, y como una consecuencia lógica

los materiales, el antiguo dueño puede intentar la actio de tigno iuncto por el doble de los daños y además reclamar los materiales cuando la edificación se viene abajo. Si el constructor estaba de buena fe, en cambio, y los materiales fueron robados por un tercero, el antiguo dueño puede intentar la actio de tigno iuncto, pero no puede después reclamar los materiales en ningún momento.

${ }^{33}$ Corbino, Alessandro, Inosservanza di doveri privati in etá decenvirale, en CAPOgrossi Colognesi, Luigi y Cursi, María Floriana (eds.), Forme di responsabilitá in etá decenvirale (Napoli, Jovene, 2008), pp. 28 ss. A propósito de los factores subjetivos de justificación en relación con la materia que tratamos, señala: "la disciplina del tignum iunctum sembra presupporre, ad esempio, la necesita del dolo specifici per la responsabilitá da furtum”.

${ }^{34}$ KASER, Max, Typisierter "dolus", cit. (n. 23), pp. 91 ss.

35 Talamanca, Mario, Istituzioni di diritto romano (Milano, Giuffrè, 1990), p. 419. Se inclina en este mismo sentido, GuZMÁN BRITo, Alejandro, Derecho privado romano (Santiago, Thomson Reuters, 2013), II, p. 284, que coloca esta acción directamente entre las acciones especiales de hurto.

${ }^{36}$ Aunque desde otra perspectiva, lo dice también el mismo autor en una obra más reciente. Véase Talamanca Mario, Delitti e pena privata nelle XII Tavole, en Capogrossi ColognesI, Luigi y Cursi, María Floriana (eds.), Forme, cit. (n. 33), pp. 52 ss. El autor comenta que en la legislación decenviral hay diversas formas de ilícitos a los cuales se asocia una pena pecuniaria (os fractum; iniuria; arbores furtum caesae); hay otros en que la pena pecuniaria era fijada en proporción al daño infligido al ofendido (furtum conceptum et oblatum; furtum nec manifestum; furtum manifestum; hurto nocturno cometido por un impúber; vindicia falsa; incendio culposo). Señala que existen algunos otros casos de acciones con penas pecuniarias, cuya calificación jurídica y palingenesia es más dudosa. Entre estos casos se encuentra la actio de tigno iuncto, cuya pena (D. 47,3,1, pr. Ulp. 37 ad ed. y 6,1,23,6-Gai. 2 rer. cott.) es idéntica a la del furtum nec manifestum. 
de lo anterior, que la acción no puede extenderse al caso del constructor de buena fe, lo cual es inconcebible, al tratarse de una acción penal.

Por lo demás si solamente se trata de una utilización de los materiales ajenos sin saber que lo eran, parece incomprensible que el derecho castigue al dueño de lo construido con una acción por el doble del valor de los mismos. También parece injusto que, además de pagar el doble de los materiales, se vea enfrentado más adelante a la acción reivindicatoria cuando se destruya el edificio. La cumulatividad de ambas acciones, en otras palabras, hace difícilmente aceptable que la actio de tigno iuncto haya procedido en caso de simple apropiación de cosas ajenas con ignorancia de que ellas lo eran.

Otro punto interesante es la procedencia de la acción reivindicatoria respecto de los materiales una vez que el edificio haya desaparecido como tal. Este régimen es prueba de que los romanos antiguos admitían una propiedad latente o durmiente sobre los materiales de la construcción, que despertaba cuando el edificio perdía integridad ${ }^{37}$.

Según señala con agudeza Guarino ${ }^{38}$, este régimen es congruente con el alto valor de algunos materiales (vigas de madera, incrustaciones, elementos ornamentales) y con la poca duración de gran parte de los edificios antiguos no monumentales, hechos especialmente de madera.

En relación con la base textual que hemos mencionado más arriba, seguiremos la tendencia de los autores que sostienen la sustancial autenticidad de esos textos, y la naturaleza penal de la actio de tigno iuncto. Y también nos sumamos a la doctrina que sostiene que en la época de Justiniano la acción de tigno iuncto habría quedado en cierto sentido despojada de su carácter penal, transformándose en una acción

Ante la duda que presenta la redacción del texto de Paulo, que parece sugerir la existencia de una acción antigua, es decir, anterior a la ley de las XII Tablas, prefiere la más nítida redacción de Ulpiano, para quien la acción habría aparecido por primera vez en la legislación decenviral. Habría sido, pues, una solución frente a la prohibición, contenida en la misma ley, de separar la viga unida. También estaría el caso de la acción para la restitución del depósito, cuya pena es también in duplum, que parece también una modalidad especial de la actio furti nec manifesti.

${ }^{37}$ Lo afirma Schulz, Fritz, Derecho clásico romano (trad. cast., Barcelona, Bosch, 1960), \$

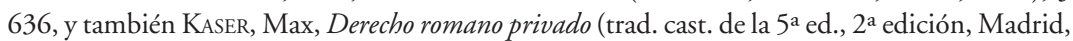
Reus, 1982), p. 122. En todo caso, como recuerda BiONDI, Biondo, cit. (n. 9), p. 245, n. 32, no es un tema pacífico. Un buen resumen de esta disputa doctrinal se encuentra en PASQUINO, Paola, cit. (n. 31), p. 20, n. 29 y pp. 21 ss. La controversia -antigua- se produce entre Guarneri Citati, que habla de una propiedad dormida, no extinguida, y Ratti, para quien la propiedad, extinguida por la incorporación de los materiales al edificio, renace cuando éste pierde su integridad (destrucción natural o demolición). La argumentación de GUARNERI CITATI, Andrea, La cosidetta accessione separabile e i suoi effeti, en Annali Palermo, 14 (1930), pp. 233 ss. descansa, en esencia, en el régimen general de la accesión: aunque se produce un aumento patrimonial en el dueño de la cosa considerada principal, el dueño de lo accesorio puede intentar la actio ad exhibendum. De este modo, en el derecho romano es posible la existencia de una propiedad sobre la cosa en su conjunto y otra sobre los materiales. Esta posibilidad, sin embargo, está impedida en los casos de inaedificatio debido a la prohibición decenviral de separar los materiales incorporados al edificio. La propiedad sobre los elementos de la construcción sería, por tanto, una propiedad dormida que despierta cuando el edificio pierde su integridad.

${ }^{38}$ Guarino, Antonio, cit. (n. 19), p. 668. 
de naturaleza indemnizatoria ${ }^{39}$. Esta sería la razón por la cual, en Inst. 2,1,29 ${ }^{40}$, la cumulatividad de esta acción con la posterior reivindicatoria es imposible.

\section{La recepción del problema en el artículo 668 del Código Civil chileno}

Antes de entrar al análisis de esta norma, debemos destacar que el artículo experimenta una variación entre el Proyecto de $1853^{41}$ y el Proyecto Inédito ${ }^{42}$. La versión de este último es la que se plasma en la redacción definitiva del artículo 688 ${ }^{43}$. A mi modo de ver, el artículo 804 del Proyecto Inédito, al introducir un inciso segundo, permite comprender con mayor exactitud lo que puede pedir el dueño de los materiales siempre y en todo caso, y lo que puede reclamar además, según sea su disposición subjetiva. Así, el dueño del suelo deberá pagar en todo

${ }^{39}$ Sobre esta doctrina, pueden verse, por ejemplo, HinCKER, Hannes, cit. (n. 30), p. 120 ss., y GUARINO, Antonio, cit. (n. 19), p. 667, n. 58.5.3.

${ }^{40}$ Inst. 2,1,29: Cum in suo solo aliquis aliena materia aedificaverit, ipse dominus intellegitur aedificii, quia omne quod inaedificatur solo cedit. nec tamen ideo is qui materiae dominus fuerat desinit eius dominus esse: sed tantisper neque vindicare eam potest neque ad exhibendum de ea re agere propter legem duodecim tabularum, qua cavetur, ne quis tignum alienum aedibus suis iniunctum eximere cogatur, sed duplum pro eo praestat per actionem quae vocatur de tigno iuncto (appellatione autem tigni omnis materia significatur ex qua aedificia fiunt): quod ideo provisum est, ne aedificia rescindi necesse sit. sed si aliqua ex causa dirutum sit aedificium, poterit materiae dominus, si non fuerit duplum iam consecutus, tunc eam vindicare et ad exhibendum agere. Justiniano, que parece dar a esta acción una función más bien indemnizatoria, prohíbe la posterior reivindicatoria, para evitar de este modo, un enriquecimiento sin causa.

${ }^{41}$ Art. 804 del Proyecto de 1853: "[inc. 10] Si se edifica con materiales ajenos en suelo propio, el dueño del suelo se hará dueño de los materiales por el hecho de incorporarlos en la construcción; pero estará obligado a pagar al dueño de los materiales su justo precio, u otro tanto de la misma naturaleza, calidad $i$ aptitud, $i$ a indemnizarle los perjuicios, quedando ademas sujeto, si ha procedido de mala fe, a la acción criminal competente. [inc. 20] La misma regla se aplica al que planta o siembra en suelo propio vejetales o semillas ajenas. Miéntras los materiales no están incorporados en la construcción o los vejetales arraigados en el suelo, podrá reclamarlos el dueño". Al pie del artículo figura una nota que conecta el inciso $1^{\circ}$ de esta norma con el artículo 554 del Código Civil francés de 1804, que dice: "Si le maitre du sol plante, construit, opére, avec matériaux d'un source étrangére, il en doit la valeur; il devra même plus, mais en payant le tout, ils ne sont pas rendus". Code Civil en vers Francais (Lyon, A. Storck Imprimeur, Rue de l'Hótel-d-Ville 78, Paris, A' Chêrié, Librairie Universelle, 1882). La traducción dice: "El propietario del suelo que hiciere construcciones, plantaciones u obras con materiales ajenos, debe abonar su valor calculado en la fecha del pago; puede ser además condenado al resarcimiento de daños y perjuicios si ha lugar: pero el dueño de los materiales no tiene derecho a retirarlos”. La disposición refuerza la idea proveniente del derecho justinianeo que insiste en la pérdida del dominio de los materiales por incorporarse ellos a la construcción, y añade además la indemnización de perjuicios cuando haya lugar a ella.

${ }^{42}$ Art. 804 del Proyecto Inédito: "[inc. 10] Si se edifica con materiales ajenos en suelo propio, el dueño del suelo se hará dueño de los materiales por el hecho de incorporarlos en la construcción; pero estará obligado a pagar al dueño de los materiales su justo precio, u otro tanto de la misma naturaleza, calidad $i$ aptitud. [inc. 2o] Si por su parte no hubo justa causa de error, será obligado al resarcimiento de perjuicios, $i$ si ha procedido a sabiendas, quedará también sujeto a la acción criminal competente; pero si el dueño de los materiales tuvo conocimiento del uso que se hacia de ellos, solo habrá lugar a la disposicion del inciso anterior. [inc. $3^{\circ}$ ] La misma regla se aplica al que planta o siembra en suelo propio vejetales o semillas ajenas. [inc. $4^{\circ}$ ] Miéntras los materiales no están incorporados en la construcción o los vejetales arraigados en el suelo, podrá reclamarlos el dueño".

${ }^{43}$ Véase n. 4. 
caso el justo precio de los materiales u otro tanto de la misma naturaleza, calidad y aptitud. Si es que no hubo justa causa de error, además de lo ya dicho, deberá indemnizar de perjuicios; y en el caso de que se compruebe la existencia de un delito, se sumará a todo lo anterior, la acción criminal que corresponda entablar de acuerdo con el hecho ocurrido. Introduce, por último, una aclaración que se refiere al conocimiento y tolerancia del dueño de los materiales de que se hacía uso de ellos. En este supuesto, podrá reclamar tan solo el justo precio de los materiales u otro tanto de la misma naturaleza, calidad y aptitud, según dispone el inciso $1^{\circ}$.

A nuestro juicio, es muy probable que, en la redacción de la norma, Bello se haya inspirado en el proyecto de Código Civil español de García Goyena ${ }^{44}$, que, en su art. 403, señala: "[inc. 10] El que sembrare, plantare á edificare en finca propia con semillas, plantas ó materiales agenos, adquiere la propiedad de unas y otros; pero estará obligado á pagar su valor y ademas será condenado á resarcimiento de daños y perjuicios si hubiese procedido de mala fé. [inc. 20] El dueño de las semillas, plantas ó materiales nunca tendrá derecho á pedir se le devuelvan, destruyéndose la obra ó plantación" 45 .

Aunque la redacción no es idéntica, contiene los elementos esenciales del concepto que ofrece Andrés Bello. Las fuentes que utiliza este autor (García Goyena), por otra parte, claramente conectan con las distinciones que usa nuestro legislador en la versión definitiva de la norma.

En efecto, se citan como fuentes del artículo 403, las Instituciones de Justiniano $2,1,29^{46}$, que recoge la acción por el duplo, y algunas leyes del título 28, Partida Tercera, de Alfonso $\mathrm{X}^{47}$. La ley 38 de dicho título, "Como se gane o se pierde el señorio de los ladriellos, ó de los pilares ó de la madera que home mete en su labor ó en su casa" ${ }^{48}$ recoge el principio romano de la prohibición de separar los materiales introducidos en la construcción, y recuerda que éste se inspira en la necesaria mantención de las ciudades y las villas, y alude, como contrapartida de esta prohibición, la posibilidad de demandar por el doble del valor de los materiales.

${ }^{44}$ El conocimiento de la obra de García Goyena -Concordancias, motivos y comentarios del Código Civil Español, de 1852- por parte de Andrés Bello es seguro. Así lo dice GuZMÁN Brito, Alejandro, Andrés Bello codificador (Santiago, Editorial Universitaria, 1982), I, p. 423. Lira Urquieta, Pedro, El Código Civil chileno y su época (Santiago, Editorial Jurídica de Chile, 1956), pp. 75 ss. afirma que la obra fue conocida en Chile antes de la redacción definitiva del Proyecto de 1853, y detalla, en las pp. 75 a 98, las partes de nuestro Código que habrían recibido influencia de este proyecto. En concreto, en p. 84 señala que la accesión del Código Civil chileno no presenta diferencias apreciables.

${ }^{45}$ García Goyena, Florencio, cit., (n. 8).

${ }^{46}$ Véase n. 40.

${ }^{47}$ Hemos consultado la versión digital que ofrece la Junta de Castilla y León (Conserjería de Cultura y Turismo 2009-2010), Madrid, Imprenta Real 1807. Disponible en https:/ bibliotecadigital.jcyl.es.

48 "Metiendo algun home en su casa ó en alguna otra obra que ficiese cantos, ó ladriellos, ó pilares, ó madera ó otra cosa semejante que fuese agena, despues que alguna destas cosas fuere asentada ó metida en labor, non la puede demandar aquel cuya es la obra, quier haya buena fe quier mala en metiéndola hi. Et esto tovieron por bien los sabios antiguos que fuese guardado por apostura et por nobleza de las cibdades et de las villas, que las obras que fueren hi fechas non las derriben por tal razón como esta; pero tenudo es de dar el prescio doblado de lo que valiere la cosa á aquel cuya era". 
La ley 16 del mismo título, agrega o precisa que la acción por el duplo procede cuando el constructor está de buena fe; si estaba de mala fe debe pagar todos los "daños y menoscabos" que se siguieron de ese apoderamiento.

García Goyena, entonces, aunque se inspira en las fuentes antiguas mencionadas, en la redacción del artículo 403 introduce una importante variación respecto del derecho antiguo: elimina la acción para reclamar el doble del valor de los materiales. Le parece más conforme a equidad y a los principios generales del derecho que únicamente se condene al pago del valor de los materiales, en el caso de buena fe; y en el de mala fe, añade la responsabilidad por daños y perjuicios, ahora sí en el mismo sentido que lo hacía la mencionada ley de las Partidas. A nuestro modo de ver, García Goyena lleva hasta las últimas consecuencias la decisión que se refleja en Instituciones 2,1,29 de Justiniano: la pérdida del dominio de los materiales, de algún modo exige el pago de un valor equivalente. Aunque Justiniano no lo dice abiertamente, sabemos que en esta época la acción por el duplo ya no tenía un cariz penal sino más bien indemnizatorio (se desprende de la incompatibilidad de esta acción con la posterior reivindicatoria, como ya hemos señalado). Siendo así las cosas, García Goyena ya no le ve el sentido al pago del duplo, que se asocia de manera más apropiada a una conducta dolosa.

Veamos, a continuación, el tratamiento que hace el artículo 668 en relación con esta materia: el que edifica en su suelo con materiales ajenos ${ }^{49}$, se hace dueño de los materiales incorporados a la construcción, aunque debe pagar "su justo precio, u otro tanto de la misma naturaleza, calidad y aptitud'.

Recordando lo que aparece en las fuentes romanas, y teniendo en cuenta las probables fuentes directas de este artículo, podemos decir lo siguiente:

a) La norma, en aplicación de la regla superficies solo cedit, sobreentendió que el dueño del suelo se hace propietario del edificio construido sobre él, y por ser del todo evidente, no lo indicó expresamente.

b) Se produce una incorporación definitiva de los materiales de construcción en el edificio, es decir, la pérdida del dominio respecto de ellos ${ }^{50}$. Es la razón, por otra parte, de que se omita toda mención a la prohibición antigua de separar las vigas de las construcciones, que parece superflua si es que ya se ha perdido el dominio sobre los materiales. En otras palabras, la prohibición antigua de separar los materiales está implícita, y es consecuencia de la pérdida del dominio de los

${ }^{49}$ El legislador menciona también los otros supuestos (plantación y siembra), pero centra su atención en el caso de la construcción.

${ }^{50}$ En algunos códigos modernos la solución es distinta, y quizás más cercana al derecho romano. Así, por ejemplo, en el art. 360 del Código Civil español, que admite el ius tollendi del dueño de los materiales siempre que no menoscabe la obra construida; el art. 935 del Código Civil italiano que habla también del ius tollendi, exigible a través de una acción reivindicatoria dentro de los seis meses desde que se produjo la incorporación; el art. 671 del Código Civil suizo que permite ejercer la reivindicatoria si es que los materiales fueron empleados sin el consentimiento de su dueño. Cosa distinta establece el derecho alemán, que no admite reserva de propiedad de los materiales. Vid. a propósito de este punto, ENNECERUs, KIPP, WolfF, Tratado de derecho civil, derecho de cosas ( $8^{\mathrm{a}}$ ed., trad. de la 32a ed. alemana con estudios de comparación y adaptación a la legislación y jurisprudencia española por Blas Pérez y José Alguer, Barcelona, Bosch, 1936), III, pp. 428 ss. 
materiales, que opera, como dice el inciso $1^{\circ}$, por incorporación de los materiales a la construcción. Y, en el mismo sentido, la única forma en que el dueño de los materiales puede recuperarlos es cuando ellos todavía no se hayan incorporado a la construcción, tal como dice el inciso final del artículo.

c) Por otra parte, aunque relacionado con el punto anterior, el artículo no menciona una acción reivindicatoria para recuperar los materiales cuando el edificio pierda su integridad. En otras palabras, el dominio sobre los materiales se ha perdido indefectiblemente; no está "dormido" o latente hasta que el edificio pierda su consistencia, como se desprendía de las fuentes romanas.

d) Se omite la acción de tigno iuncto, con su característica condena al doble del valor de los materiales, que, de acuerdo con lo ya dicho, es sustituida por una acción indemnizatoria por el valor de los mismos. En esto la norma es el corolario de una evolución interesante de esta acción, de origen estrictamente penal y asociado al hurto, que termina por considerarse un recurso para obtener una indemnización (tiempos de Justiniano), y queda despojada, ya en el derecho de la codificación, de su característica condena al duplo.

e) Además del valor de los materiales, si es que no hubo un motivo razonable de error, es decir, si hubo mala fe en el constructor, se agregará una indemnización de perjuicios; e incluso una acción criminal en el caso de que el constructor haya procedido con dolo. Esta acción ya no es, pues, una acción penal específica como era la actio de tigno iuncto; se trata ahora de algunos de los tipos penales generales (hurto, robo, estafa).

\section{ANÁLISIS DEL SEGUNDO SUPUESTO: LA CONSTRUCCIÓN DE UN EDIFICIO EN SUELO AJENO}

\section{El dominio del suelo y la propiedad sobre los materiales}

Como hemos dicho más arriba, el segundo supuesto relacionado con la edificación es aquel que se produce cuando una persona construye sobre suelo ajeno.

Hemos señalado, al inicio de este trabajo, que, de acuerdo con el principio superficies solo cedit, el edificio se hace de quien es dueño del terreno, y no del constructor. En relación con la fuerza del principio superficies solo cedit en este segundo supuesto, existen varios textos ${ }^{51}$. Es importante señalar -en este punto seguimos a Girard ${ }^{52}$-, que la antigua prohibición de separar los materiales incorporados al edificio se aplica no solo al primer supuesto (edificación con materiales

${ }^{51}$ La selección de textos es de Musumeci, Francesco, Inaedificatio, cit. (n. 14), pp. 124 ss., pero en ella coincide la mayoría de los autores que han tratado esta materia. Gai. Institutiones, 2,73: "Praeterea id quod in solo nostro ab aliquo aedificatum est, quamvis id ille suo nomine aedificaverit, tamen ratione naturali nostrum fit, quia superficies solo cedere dicitur"; D. 48,18,2Gai. 25 ad ed prov.; D. 41,1,7,12-Gai. 2 rer. cott. sive aureor.; D. 41,1,28-Pomp. 33 ad sab.; D. 24,1,31,2-Pomp. 14 ad sab.: D. 9,2,50- Ulp. 6 opin.; D. 8,14,17-Pap. 7 quaest.; C. 3,32,2Impp. Sever. et Antonin. AA Aristeneto) (a. 313); Cod. Gregor. Wisig. 3,6,2 (a. 244 o 245); C. 3,32,16-Impp. Diocletian. et Maxim. AA. et CC. Ianuario (a. 293).

${ }^{52}$ Girard, Paul, cit. (n. 18), p. 356, n. 7. Para apoyar su argumentación, trae a colación D. 6,1,59- Iul. 6 ex minic., que comentaremos también más adelante. 
ajenos en suelo propio), sino también a este segundo caso: la razón de utilidad pública es la misma.

Según dijimos en el resumen de este trabajo, la accesión del edificio al suelo provoca además un problema posesorio. El dueño del terreno, que se hace propietario del edificio, está legitimado para intentar la acción reivindicatoria, cuyo propósito es la recuperación de la posesión perdida. Veamos ahora qué sucede con el dueño de los materiales; en qué posición jurídica queda respecto de ellos. Se trata de definir, por una parte, si el dueño de los materiales permanece como tal, o pierde definitivamente el dominio de dichos materiales. Por otra parte, se trata de resolver si en el tiempo intermedio, es decir, mientras el edificio está en pie, tiene algún derecho sobre los materiales: una indemnización o un derecho de retirar los objetos introducidos en la construcción (ius tollendi).

Para Biondi ${ }^{53}$, como ya decíamos más arriba, según el derecho civil no hay indemnización para el dueño de los materiales: en virtud del principio superficies solo cedit, todas las mejoras que se incorporan en la cosa siguen la suerte del suelo. El pretor, sin embargo, invocando razones de equidad, concede al poseedor una exceptio doli contra el dominus soli que reivindica la cosa.

El detalle de este razonamiento puede encontrarse en Riccobono ${ }^{54}$, las mejoras introducidas en el fundo de otro (edificaciones, plantaciones, etc.) se incorporan -acceden- intrínsecamente a la cosa por efecto del principio superficies solo cedit. Por esta razón, el ius civile no admite el derecho a reembolso de esos gastos por medio de una acción. El derecho pretorio, sin embargo, cuando se trata de un poseedor de buena fe, permite al vencido oponer la exceptio doli para obtener el reembolso de dichos gastos. A su juicio, el fundamento de esta doctrina, que encuentra apoyo en varios textos clásicos, y en el que hay concordancia absoluta entre los juristas, se refleja muy especialmente en un texto de Juliano: D. 12,6,33. En el pasaje, cuando un tercero construye en el fundo de otro y los materiales ya se han incorporado, el poseedor no puede intentar la condictio para recuperar el valor de dichos materiales. La razón es que no existe ninguna relación obligatoria entre las partes que lo permita (condictio locum non habebit, quia nullum negotium inter nos contraheretur). Ni siquiera podría hablarse, en este caso, de un pago indebido, que sí daría origen a la condictio indebiti. La única forma de exigir el reembolso, según dice magistralmente otro texto, en este caso de Papiniano-D. 6,1,48-, es a través de una exceptio doli a favor del poseedor de buena fe: los gastos hechos en un predio que resultó después ser ajeno, no pueden reclamarse, "pero opuesta la excepción de dolo, son recobrados por razón de la equidad por ministerio del juez". En definitiva, el reembolso de los referidos gastos hechos por un poseedor de buena fe solo se ampara en la equidad (no hay razón estrictamente jurídica). En el caso del poseedor de mala fe, ni hay razón jurídica ni tampoco razón de equidad, de modo que no tiene nunca derecho al reembolso.

Esta cuestión es interesante y se observa del análisis de varios textos, los cuales se refieren a distintas situaciones, como veremos a continuación. Así, D. 24,1,31,2-

\footnotetext{
${ }^{53}$ Biondi, Biondo, cit. (n. 9), pp. 245, 278.

${ }^{54}$ Riccobono, cit. (n. 14), pp. 10 ss.
} 
Pomp. 14 ad sab.: "Si vir uxori aream donaverit et uxor in ea insulam aedificaverit, ea insula sine dubio mariti est, sed eam impensam mulierem servaturam placet: nam si maritus vindicet insulam, retentionem impensae mulierem facturam". El pasaje señala que, en el caso de que el marido done un solar a su mujer, y ésta hubiese edificado en él una casa, no hay duda de que la casa es del marido. La solución es acorde con el conocido principio de que las donaciones entre marido y mujer son nulas (el título I del libro 24, en que se coloca el texto está dedicado a las donaciones entre marido y mujer). Sin embargo, si el marido reivindicase lo que es suyo (el solar y la casa edificada sobre él), la mujer podrá oponer la retención de los gastos. Lo interesante es que, en este caso, aunque se trata de un acto o negocio nulo (la donación entre cónyuges), el derecho considera al constructor -en este caso a la mujer-como poseedor de buena fe, otorgándole el derecho de recuperar los gastos. Algo muy semejante ocurre en D.44,4,10-Marc. 3 reg.: "Cum vir aut uxor in area sibi donata aliquid aedificasset, plerisque placet doli mali exceptione posita rem servari posse". En el texto se sobreentiende que estamos también en un caso de donación entre cónyuges; de lo contrario no hablaría de uxor para referirse a la persona del edificador. Se aplica aquí una solución casi idéntica a la del caso anterior, aunque por el contexto del pasaje -colocado por Justiniano en el título IV De doli mali et metus exceptione- se hace hincapié en la posibilidad de oponer la excepción de dolo malo para obtener la recuperación de los gastos. La inserción del final es perfectamente coherente con la posibilidad de oponer la exceptio para exigir el reembolso de los gastos: el edificio puede conservarse, puede seguir en pie $^{55}$.

Ya fuera del ámbito de las donaciones entre cónyuges, y en cambio, hablando de la edificación en suelo ajeno en términos más generales, puede verse D. 44,4,14Paul. 3 resp. "Paulus respondit eum, qui in alieno solo aedificium extruxerit, non alias sumptus consequi posse, quam possideat et ab eo dominus soli rem vindicet, scilicet opposita doli mali exceptione". En el texto se señala que la única forma de recuperar los gastos derivados de la construcción en suelo ajeno es oponiendo la exceptio doli mali ante la acción reivindicatoria del dueño. Esto supone, naturalmente que se trata de un edificador de buena fe.

Según la opinión mayoritaria de la doctrina, debidamente apoyada en las fuentes ${ }^{56}$, el constructor en suelo ajeno no tiene derecho a demoler la edificación para apoderarse de los materiales incorporados al edificio. Sin embargo, si actuó de buena fe, puede oponer, a la acción reivindicatoria del dueño del suelo, la ya mencionada excepción de dolo, a fin de conseguir una indemnización por estas impensas, que, de acuerdo con D. 6,1,38, serían mejoras útiles.

En cuanto a este punto, Schulz ${ }^{57}$ señala que, a diferencia del primer caso, aquí el dueño del suelo no solo se hace propietario del edificio, sino también de los materiales de los que está hecho. Aunque la construcción perdiera después su

\footnotetext{
${ }^{55}$ Un análisis interesante de estos textos hace BürGE, Alfons, Retentio im römischen Sachenund Obligationenrecht (Zürich, Schulthess Polygrapischer Verlag, 1979), pp. 123 s.

${ }^{56}$ Girard, Paul, cit. (n. 18), p. 356 y, en especial, n. 7.

${ }^{57}$ Schulz, Fritz, cit. (n. 37), $\$ 636$. No se aplica entonces a este supuesto la doctrina de la propiedad $\mathrm{d}$ o $\mathrm{r} \mathrm{m}$ i d a sobre los materiales.
} 
consistencia, el dominio de los materiales no vuelve atrás. Solo le cabe, al que era dueño de los materiales oponer una exceptio doli frente a la acción reivindicatoria del dueño del suelo. También insiste en la pérdida de los materiales, Meincke ${ }^{58}$.

Para Musumeci ${ }^{59}$, en cambio, el derecho sobre los materiales en este segundo supuesto, se mantiene en el precedente titular. Para hacer esta afirmación, invoca muy especialmente dos textos. En el primero, D. 6,1,59-Iul. 6 ex Min. ${ }^{60}$, se habla claramente de la propiedad de los materiales por parte del constructor (las cosas incorporadas al edificio, una vez que han sido quitadas, vuelven a su antigua condición). En su opinión, el tono que usa el jurista parece indicar que se trata de una doctrina comúnmente aceptada, y que no existirían opiniones discordantes. En el segundo, D. 7,1,15 pr.-Ulp. 18 ad sab. ${ }^{61}$, Ulpiano habla de un usufructuario, que solo podrá vindicar los materiales de construcción una vez destruido el edificio. De esa afirmación se deduce que dichos materiales le pertenecen ${ }^{62}$.

El autor (Musumeci), sobre la base de los pasajes que acabamos de mencionar y de algunos otros ${ }^{63}$, deduce que la prohibición de separar la viga unida, proveniente de la legislación decenviral, se aplica también y, en toda regla, a los casos de inaedificatio en suelo de un tercero. Pero dicho impedimento rige solo en relación al dueño de los materiales, no al propietario del suelo. En efecto, mediante diversos recursos procesales, el dueño del fundo podía conseguir la destrucción del edificio por parte del poseedor ${ }^{64}$.

${ }^{58}$ MeInCKe, Jens Peter, Superficies solo cedit, en SZZ., 88 (1971).

${ }^{59}$ Musumeci, Francesco, Inaedificatio, cit. (n. 14), pp. 134 ss.

${ }^{60}$ D. 6,1,59-Iul. 6 ex Min.: "Habitator in aliena aedificia fenestras et hostia imposuit, eadem post annum dominus aedificiorum dempsit; quaero, is, qui imposuerat, possetne ea vindicare? respondit, posse: nam quae alienis aedificiis conexa essent, ea quamdiu iuncta manerent, aeorundem aedificiorum esse; simul atque inde dempta essent, continuo in pristinam causam reverti".

${ }^{61}$ D. 7,1,15 pr. Ulp. 18 ad sab.: Sed si quid inaedificaverit, postea eum neque tollere hoc neque refigere posse: refixa plane posse vindicare.

${ }^{62}$ Un texto interesante, que también comenta el autor en diversas partes de su obra [por ej. Musumeci, Francesco, Inaedificatio, cit. (n. 14), p. 201], es C. 3,32,2,1: Imperatores Severus, Antoninus. "Sed et id, quod in solo tuo aedificatum est, quoad in eadem causa manet, iure ad te pertinet. si vero fuerit dissolutum, materia eius ad pristinum dominium redit, sive bona fide sive mala fide aedificium extructum sit, si non donandi animo aedificia alieno solo imposita sint. (a. 213 pp. xii k. nov. antonino a. iiii et balbino conss.". Diversos autores dudan de la parte del texto que permite el retiro de los materiales tanto a favor del poseedor de buena como el de mala fe, a menos que hayan realizado la construcción con animus donandi. Así lo dice GIRARD, Paul, cit. (n. 18), p. 357, n. 1. A su juicio, la afirmación presenta un contrasentido: si el constructor estaba de mala fe, difícilmente puede haber actuado con ánimo de donar, más bien tenía la intención de cometer un hurto. Y si estaba de buena fe, tampoco pudo haber tenido animus donandi, justamente porque no sabía que se trataba de una propiedad ajena.

${ }^{63}$ Por ejemplo, D. 46,3,98,8-Paul. 15 quaest., que hace referencia a la prohibición de separar (sed interim id solvi prohibitur).

${ }^{64} \mathrm{La}$ actio quod metus causa, que contenía cláusula arbitraria, podía concluir con una restitución de las cosas al estado anterior, que se traducía en una obligación de destruir la edificación: D. 4,2,9 pr. Ulp. 11 ad ed. También se daba el interdicto quod vi aut clam o el uti possidetis, en virtud de los cuales, el constructor podía verse constreñido a destruir la obra: D. 39,1,5,10- Ulp. 52 ad ed.; D. 43,24,15,17-Ulp. 71 ad ed.; D. 43,17,3,9- Ulp. 69 ad ed. Por otra parte, el dueño del suelo podía acudir a los recursos que se preveían para la aparición de 
A juicio de Musumeci ${ }^{65}$, habrían sido los compiladores quienes hablan de una pérdida de los materiales por parte del constructor poseedor. Así se reflejaría especialmente en los siguientes textos: D. 41,1,7,12-Gai. 2 rer. cott. $^{66}$ y Inst. $2,1,30^{67}$, muy semejantes entre sí. En relación con estos textos, Musumeci comenta que la doctrina de los compiladores coincide con el pensamiento de los juristas clásicos en cuanto al tratamiento que se da al poseedor de buena fe, -que dispone de la exceptio doli- y en parte introducen un principio nuevo, que es la pérdida de los materiales por parte del constructor de mala fe. Si el poseedor sabía que construía sobre suelo ajeno se entiende que los ha enajenado por su propia voluntad, y no puede después reivindicar los materiales cuando se destruya la edificación. Ambos pasajes resaltan de un modo especial la existencia de buena o mala fe en el constructor, que se asocia al conocimiento o no de la ajenidad del suelo en que se construye, y que tiene como consecuencia la pérdida o no de los materiales de la construcción.

Dicha doctrina no concuerda, en cambio, con los textos clásicos en lo referido a la posición jurídica que el poseedor tiene sobre los materiales introducidos en la construcción ${ }^{68}$, que afirman sin lugar a dudas la permanenencia del dominio sobre los materiales después de la conjunción.

En relación con la retención del poseedor de buena fe, veremos a continuación un pasaje (analizado con detalle por Riccobono) donde figuran las distintas hipótesis en relación con la materia, y los modos posibles de resolución judicial: D. 6,1,38-Celsus 3 dig. ${ }^{69}$. El texto trata de un poseedor de buena fe que edificó o

una obra nueva (operis novi nuntiatio), con el consiguiente peligro - para el constructor- de verse enfrentado a un interdicto demolitorio: D. 39,1,5,8 y 9-Ulp. 52 ad ed.

${ }^{65}$ Musumeci, Francesco, Inaedificatio, cit. (n. 14), pp. 198 ss. También MeInCKe, Jens Peter, cit. (n. 58), pp. 154, coloca D. 41,1,7,12 y Inst. 2,1,30 en paralelo, y destaca la similitud de la redación de ambos textos.

${ }^{66}$ D. 41,1,7,12-Gai. 2 rer. cott.: "Ex diverso si quis in alieno solo sua materia aedificaverit, illius fit aedificium, cuius et solum est et, si scit alienum solum esse, sua voluntate amisisse proprietatem materiae intellegitur: itaque neque diruto quidem aedificio vindicatio eius materiae competit. certe si dominus soli petat aedificium nec solvat pretium materiae et mercedes fabrorum, poterit per exceptionem doli mali repelli, utique si nescit qui aedificavit alienum esse solum et tamquam in suo bona fide aedificavit: nam si scit, culpa ei obici potest, quod temere aedificavit in eo solo, quod intellegeret alienum".

${ }^{67}$ Inst. 2,1,30: "Ex diverso si quis in alieno solo sua materia domum aedificaverit, illius fit domus, cuius et solum est. sed hoc casu materiae dominus proprietatem eius amittit, quia voluntate eius alienata intellegitur, utique si non ignorabat, in alieno solo se aedificare: et ideo, licet diruta sit domus, vindicare materiam non poterit. certe illud constat, si in possessione constituto aedificatore, soli dominus petat domum suam esse, nec solvat pretium materiae et mercedes fabrorum, posse eum per exceptionem doli mali repelli, utique si bonae fidei possessor fuit qui aedificasset: nam scienti, alienum esse solum, potest culpa obici, quod temere aedificaverit in eo solo quod intellegeret alienum esse".

${ }^{68}$ Musumeci, Francesco, Inaedificatio, cit. (n. 14), pp. 200 ss. El autor destaca a propósito de este asunto los siguientes textos: D. 44,2,7,2-Ulp. 75 ad ed.; C. 3,32,2,1-Impp. Sever. et Antonin. AA. Aristaeneto, y aunque no referidos directamente a lo que analizamos, también D. 7,1,15 pr. Ulp. 18 ad sab.; D. 9,2,27,32-Ulp. 18 ad ed.; D. 6,1,59-Iul. 6 ex Min.

${ }^{69}$ D. 6,1,38, Celsus 3 dig.: "In fundo alieno, quem imprudens emeras, aedificasti aut conseruisti, deinde evincitur: bonus iudex varie ex personis causisque constituet. finge et dominum eadem facturum fuisse: reddat impensam, ut fundum recipiat, usque eo dumtaxat, quo pretiosior factus est, 
plantó en suelo ajeno ${ }^{70}$. El dueño del fundo, para recobrar la posesión del predio que reivindica, deberá pagar los gastos útiles realizados en él. Pero el problema se plantea si es pobre; si no tiene cómo pagarlos, deberá permitir que el constructor evicto (poseedor de buena fe) retire lo que pueda, sin deterioro del fundo.

En primer lugar, Riccobono ${ }^{71}$, hace una distinción para establecer el modo de restituir las impensas ${ }^{72}$. El juez, cuando el poseedor ha opuesto la correspondiente exceptio doli, tiene amplios poderes para valorar todos los elementos objetivos y subjetivos de modo que el reembolso no resulte gravoso para el que reivindica su propiedad. Por eso, el propietario no deberá verse constreñido a contraer deudas o a enajenar el fundo para pagar esas impensas. El jurista, según detalla Riccobono, se pone en diversas situaciones:

a) Si el propietario que reivindica iba a vender el fundo una vez recuperado, y el precio de éste era superior gracias a estas mejoras, debe restituir los gastos al poseedor vencido. En otras palabras, la última parte del texto define cómo ha de calcularse, en este caso, el valor de la condena de la acción reivindicatoria: ha de deducirse el valor de las mejoras introducidas por el poseedor (nisi reddit, quantum prima parte reddio portere diximus, eo deducto tu condemnandus es).

b) Si, por el contrario, el propietario es pobre, y el reembolso de esas impensas le supone verse privado de los sepulcros de sus antepasados, no estaría obligado a realizar esas restituciones. El poseedor podría, en cambio, retirar las cosas incorporadas en la construcción, siempre que el fundo no quede más deteriorado que si sobre él no se hubiese edificado.

Se trata, según comenta el autor, del ius tollendi, que Celso, como jurista proculeyano, defiende en perfecta continuidad con Labeón ${ }^{73}$. A juicio de Celso este derecho de retiro de los materiales debe ser ejercido con respeto a la prohibición decenviral. En otras palabras, Celso y en general los proculeyanos, admiten este

et si plus pretio fundi accessit, solum quod impensum est. finge pauperem, qui, si reddere id cogatur, laribus sepulchris avitis carendum habeat: sufficit tibi permitti tollere ex his rebus quae possis, dum itane deterior sit fundus, quam si initio non foret aedificatum. constituimus vero, ut, si paratus est dominus tantum dare, quantum habiturus est possessor his rebus ablatis, fiat ei potestas: neque malitiis indulgendum est, si tectorium puta, quod indux eris, picturasque corradere velis, nibil laturus nisi ut officias. finge eam personam esse domini, quae receptum fundum mox venditura sit: nisi reddit, quantum prima parte reddio portere diximus, eo deducto tu condemnandus es".

${ }^{70}$ Nos centraremos en el caso de la edificación, que es el supuesto en que se detiene el jurista.

${ }^{71}$ Riccobono, Salvatore, cit. (n. 14), pp. 7 ss.

${ }^{72}$ Señala que la restitución de los gastos necesarios se hace en la medida del gasto invertido en mano de obra y en materiales incorporados; para la compensación de los gastos útiles se sirve del texto que estudiamos, y para los gastos voluptuarios establece, en armonía con la doctrina comúnmente aceptada, que no hay derecho a reembolso. Así lo dice también MUSUMECI, Francesco, Inaedificatio, cit. (n. 14), pp. 149, recordando lo señalado en D. 5,3,39,1- Gai. 6 ad ed. prov.

${ }^{73}$ Acerca de la controversia entre proculeyanos y sabinianos en torno al ius tollendi, pueden verse, según Riccobono, Salvatore, cit. (n. 14), p. 8, n. 7, los siguientes textos: D. 19,2,19,4 (Labeón); D. 24,1,63 (Neracio); D. 6,1,38 (Celso), por parte de los proculeyanos, y D. 6,1,59 (Juliano); D. 7,1,15 pr. (Ulpiano); C. 3,32,2 (año 213), por parte de los sabinianos. También lo dice VolterRA, Eduardo, cit. (n. 22), p. 338: los proculeyanos admitían el derecho de separar dichos materiales incluso mientras el edificio era todavía existente y permanecía de modo íntegro. 
derecho de separar los materiales unidos a la construcción, y no lo consideran una violación de la antigua prohibición decenviral, sino una interpretación racional de la misma. De este modo, si los objetos conservan su individualidad física -puertas, ventanas, estatuas, mármoles, tejas, columnas decorativas (no vigas maestras), etc.-no habría inconveniente en retirarlos. Esta doctrina, recuerda el autor, que fue tan combatida en la época clásica, termina por imponerse en la compilación justinianea ${ }^{74}$.

De todos modos, el jurista establece una clara limitación en el ejercicio de este ius tollendi: la separación de esos objetos debe arrojar alguna utilidad al poseedor, y en consecuencia, no están permitidos al poseedor los actos que solo pretenden provocar un daño (retirar el estuco o las pinturas) ${ }^{75}$.

También puede verse el texto de Ulpiano, recogido en D. 6,1,37-Ulp. 17 ad ed., que resulta ya más extremo: "Iulianus libro octavo digestorum scribit: si in aliena area aedificassem, cuius bonae fidei quidem emptor fui, verum eo tempore aedificavi, quo iam sciebam alienam, videamus, an nihil mibi exceptio prosit: nisi forte quis dicat prodesse de damno sollicito. puto autem huic exceptionem non prodesse: nec enim debuit iam alienam certus aedificium ponere: sed hoc ei concedendum est, ut sine dispendio domini areae tollat aedificium quod posuit". El pasaje de Ulpiano -colocado en sede de acción reivindicatoria- se apoya en una cuestión planteada por Juliano: qué sucede en el caso de un comprador, adquirente de buena fe, que construye en suelo ajeno cuando ya es sabedor de la ajenidad de la cosa. En opinión de Ulpiano, a pesar de tratarse de un poseedor de buena fe, no puede oponer la exceptio doli, que se da a quienes han hecho impensas -en este caso útiles-sobre la cosa. En otras palabras, no se aplica en su favor el principio "mala fides superveniens non nocet"; Ulpiano da a este comprador el tratamiento de un poseedor de mala fe. Pero se le puede conceder que, a su propio cargo, derribe el edificio levantado. Obviamente en el pasaje no se plantea la cuestión del dominio del edificio: en virtud del principio "superficies solo cedit", es del dueño del terreno. El jurista, pues, focaliza su atención en el aspecto económico; piensa en los gastos que supuso la construcción del edificio y, teniendo en cuenta que el constructor no puede cobrar al dueño del terreno el valor de lo construido -se le considera poseedor de mala fe-, al menos debe permitírsele destruir el edificio, para rescatar, por ejemplo, algunos materiales. A mi modo de ver, el jurista no quiere establecer una regla general que permita la destrucción de lo construido en suelo ajeno por parte del constructor, y en este sentido, omite toda referencia a la prohibición decenviral ${ }^{76}$. En efecto, probablemente en su opinión, con este criterio no existía una infracción a la regla que impedía la separación del tignum iunctum.

${ }^{74}$ La opinión de Riccobono ayuda a comprender mejor este y otros textos que admiten el ius tollendi y evitar considerarlos en todo caso interpolados. Es el caso, por ejemplo, de KASER, Max, Derecho Romano, cit. (n. 37), p. 127; a su juicio, D. 6,1,38 estaría interpolado: es Justiniano quien otorgó a todo poseedor (de buena o mala fe) el ius tollendi.

${ }^{75}$ Aunque no se trata de la materia que trabajamos en este artículo, Riccobono, Salvatore, cit. (n. 14), p. 9, señala que la afirmación hecha por el jurista constituye uno de los gérmenes de la doctrina que prohíbe los actos emulativos.

${ }^{76}$ BÜrge, Alfons, cit. (n. 55), especialmente en pp. 73 s. conecta este texto con D. 
En resumen, la prohibición de separar la viga unida (tignum iunctum), se aplica también al caso de construcción en suelo de un tercero. El poseedor de buena fe-impedido de destruir la construcción hecha en suelo ajeno- puede, sin embargo, oponer una exceptio doli para obtener el valor de las impensas útiles ${ }^{77}$. Solo en el caso de que el dueño del predio no pudiere pagarlas, existirá el derecho de retirar los objetos de la construcción, siempre que dicha separación no deteriore el edificio. De este derecho se deduce, pues, que no hay una pérdida definitiva y absoluta del dominio de los materiales.

Como puede verse, este texto combina la existencia del principio que protege la integridad del edificio con los intereses del derecho del dueño del suelo, que no podrá verse perjudicado cuando se enfrenta al derecho de retención del poseedor vencido. Si no puede pagar, deberá permitir que el poseedor retire los objetos del edificio sin provocar detrimento de la integridad del mismo.

\section{Recepción del problema en el artículo 669 del Código Civil chileno}

Antes de entrar al análisis de este texto debemos decir que hay una importante diferencia entre los proyectos que antecedieron a la redacción definitiva de esta norma. El artículo 805 del Proyecto de $1853^{78}$, si bien es escueto -solo consta de un párrafo- señala lo esencial de lo que se recogerá después en la norma definitiva. En el Proyecto Inédito ${ }^{79}$ se incorporan otras disposiciones de detalle que son las que recoge la versión final y que aparecen en el artículo 669.

50,17,206 que reprime el enriquecimiento injusto, que en el derecho común se trasformará en una regla general. Se trataría de una excepción al principio "mala fides superveniens non nocet", cuyo fundamento se encuentra en esta necesidad de evitar el desequilibrio económico y el enriquecimiento sin causa: p. 71s. En relación con este punto, puede verse también, PASQUINO, Paola, cit. (n. 31), pp. 100 ss.

${ }^{77}$ En esta materia, Musumeci, Francesco, Inaedificatio, cit. (n. 14), pp. 146 ss. ofrece una explicación distinta. A su juicio, el recurso principal para este supuesto habría sido la obtención de un pretium con carácter indemnizatorio, cuya base textual sería D. 46,3,98,8. El pasaje se aplicaría tanto a los casos de construcción en predio propio con materiales ajenos como a los de edificación en suelo ajeno. La creación de recursos más modernos, como la exceptio doli, habría desplazado o hecho menos conocido este recurso. El argumento, basado tan solo en este texto, en el que el pretium pudo haber sido tan solo una expresión poco feliz del jurista que hablaba, hace menos convincente la doctrina del autor. En efecto, la totalidad de los textos que se refieren a esta materia hablan de la exceptio doli, dado que este supuesto se produce en el marco de una reivindicatoria.

${ }^{78}$ Art. 805 del Proyecto de 1853: "Si se posee un terreno ajeno, el dominio de las plantaciones, sementeras, cercas, edificios, diques, acueductos $i$ demas construcciones que se hagan en él para conservarlo o mejorarlo, pertenecerán al dueño del terreno, con las obligaciones que respecto de los poseedores de buena o mala fe se le imponen en el título De la acción reivindicatoria".

${ }^{79}$ Art. 805 del Proyecto Inédito: "[inc. 10] El dueño del terreno en que otra persona, sin su conocimiento, hubiere edificado, plantado o sembrado, tendrá el derecho de hacer suyo el edificio, plantación o sementera, mediante las indemnizaciones prescritas a favor de los poseedores de buena o mala fe en el título De la reivindicación, o de obligar al que edificó o plantó a pagarle el justo precio del terreno con los intereses legales por todo el tiempo que lo haya tenido en su poder, i al que sembró a pagarle la renta y a indemnizarle los perjuicios. [inc. $2^{\circ}$ ] Si se ha edificado, plantado o sembrado a ciencia i paciencia del dueño del terreno, será éste obligado, para recobrarlo, a pagar el valor del edificio, plantación o sementera". 
Como ya hemos dicho al inicio de este trabajo, no contamos con las actas oficiales de la comisión revisora del proyecto de Código Civil de $1853^{80}$, de modo que, al menos por esta vía, no es posible aventurar los antecedentes en que se habría inspirado el art. 805 del Proyecto Inédito, que pasaría a ser después el actual art. $669^{81}$.

Según Claro Solar ${ }^{82}$, la norma ha sido tomada del proyecto de Código Civil español de $1851^{83}$, que en su artículo 404 decía: "El dueño del terreno en que se edificare, sembrare o plantare de buena fe, tendrá derecho a hacer suya la obra, siembra o plantación, previa la indemnización prescrita en el párrafo segundo del artículo 432, o de obligar al que fabricó o plantó a pagarle el precio del terreno, y al que sembró solamente su renta" ${ }^{84}$. La afirmación es muy plausible si se tiene en cuenta la redacción del inciso $1^{\circ}$ del artículo 669, muy similar a la del artículo 404 .

A nuestro juicio, la norma, acogiendo la tradición jurídica que ya hemos expuesto, aplica, con toda su fuerza, el principio superficies solo cedit; lo construido en suelo ajeno se hace indefectiblemente del dueño del suelo. Pero además, el artículo se hace cargo del problema que se produce cuando el dueño del suelo intenta recobrar la posesión de su terreno, pero no tiene cómo pagar las mejoras hechas en el mismo.

Es interesante destacar que la disyuntiva que ofrece dicha disposición -hacer suya la obra u obligar al constructor a comprar el terreno- (replicada en la norma de nuestro Código), no tiene un antecedente directo en las fuentes romanas. Tampoco hay rastros de esta opción en las Partidas de Alfonso X ${ }^{85}$. La ley 46, contenida en la Partida III (titulada "Cuyo es el señorio del edificio, ó de las llantas

${ }^{80}$ Véase. p. 3 (Introducción) y n. 6.

${ }^{81}$ Lo destaca GONZÁLEZ, Manuel, Construcción en suelo ajeno a ciencia y paciencia del dueño del terreno: una aproximación dogmática al inciso segundo del artículo 669 del Código Civil, en Revista Chilena de Derecho Privado, 28 (Santiago, 2017), pp. 222-231. El autor analiza el inciso $2^{\circ}$ del mencionado artículo, pero las ideas que aduce se extienden naturalmente al artículo en su conjunto. Las reflexiones que hace el autor en torno a la naturaleza de la accesión, en pp. 231 ss. son consistentes con la definición de accesión de nuestro Código, influido directamente por Pothier, donde la figura se perfila más como un aumento o engrosamiento del dominio que como una adquisición de una cosa distinta o independiente. Sobre este tema, véase, LeITAO, Francisca, La formación histórica del modo de adquirir denominado “accesión”, en Revista de Estudios Histórico-Jurídicos, 39 (Valparaíso, Universidad Católica de Valparaíso, 2008), pp. 61-117. En lo relativo a las dificultades que presenta el encasillamiento de la accesión como modo de adquirir, puede verse, SozA, María de los Ángeles, La edificación y la adquisición del dominio del edificio, en Estudios de derecho civil V, Jornadas Nacionales de derecho civil (Concepción, Abeledo Perrot, LegalPublishing, 2009). A juicio de González, la expropiación de los materiales que sufre el constructor es una consecuencia de la accesión, que provoca la pérdida de la individualidad jurídica de la cosa por su incorporación física en la cosa principal.

${ }^{82}$ Claro Solar, Luis, Explicaciones de derecho civil chileno y comparado (Santiago, Editorial Jurídica de Chile, 2013), VII (de los bienes II), p. 216.

${ }^{83}$ En relación con el conocimiento de la obra de García Goyena por parte de Andrés Bello, véase n. 44.

${ }^{84}$ García Goyena, Florencio, cit. (n. 8), I, cap. IV, Del derecho de accesión respecto de los bienes inmuebles.

${ }^{85}$ Versión digital, Junta de Castilla y León (Conserjería de Cultura y Turismo 2009-2010), Madrid, Imprenta Real 1807. Disponible en https:/bibliotecadigital.jcyl.es. 
ó árboles que home pone á buena fe en heredat agena") reproduce el contenido del texto de Celso (D. 6,1,38) que admite el ius tollendi en caso de que el dueño del suelo fuese pobre y no pudiera pagar las mejoras ${ }^{86} \mathrm{y}$ acoge el régimen de las restituciones recíprocas vigente en el derecho romano, pero no alude en modo alguno a la obligación del poseedor de comprar el terreno. La ley 47 contenida en la Partida III (titulada "Cómo pierde home el edificio que face en heredat agena ó la mies que hi siembra á mala fe"), que acoge el régimen introducido por Justiniano en cuanto a la pérdida del dominio de los materiales para el poseedor de mala $\mathrm{fe}^{87}$, y el ius tollendi, tampoco habla de la mencionada alternativa.

Como vemos, el artículo presenta, en esta parte, una originalidad respecto de las fuentes antiguas, en las cuales no existía tal opción. Podemos suponer, pues, que el autor de la disyuntiva es el propio comentarista del Código Civil español, y Andrés Bello (o los miembros de la comisión revisora) la habrían tomado directamente de García Goyena ${ }^{88}$.

Veamos pues lo que dice la disposición. A mi juicio, el núcleo de la primera parte del inciso $1^{\circ}$, es la controversia en torno a la posesión del suelo, que se resuelve, en conformidad con la historia de este supuesto, a través de la acción reivindicatoria ${ }^{89}$.

No está en juego, por ende, la adquisición del dominio del edificio, a pesar de

\footnotetext{
${ }^{86}$ Claro Solar, Luis, cit. (n. 82), pp. 217 ss. piensa que la inspiración remota de esta norma sería precisamente el texto mencionado.

${ }^{87}$ Véase n. 67.

${ }^{88}$ Tal opción aparece también en el artículo 361 del Código Civil español, cuestión que es explicable: la fuente principal del Código Civil español es la obra de García Goyena. La tesitura en que se encuentra el dueño del suelo es resuelta de formas distintas en las diversas legislaciones. Por ejemplo, en algunos códigos, el dueño puede optar entre pagar la construcción u obligar al constructor a destruir la edificación. Claro Solar, Luis, cit. (n. 82), p. 217, la solución de nuestro Código es más completa y equitativa, y respeta el derecho de accesión por cuanto da la opción al dueño del terreno, y no al edificador.

${ }^{89}$ Aunque excede con creces las pretensiones de este trabajo, debemos destacar que cuando se trata de una posesión inscrita, el que se instala en un terreno ajeno y construye en él, no hace perder la posesión civil al dueño del suelo. Sin embargo, habrá que otorgarle algún recurso para recobrar lo que es suyo, y ese recurso, teniendo a la vista los antecedentes históricos de este artículo, no puede ser otro que la acción reivindicatoria. En relación con esta materia, puede verse, por ejemplo, ETCHEBERRY, Leonor, El título en el precario: análisis jurisprudencial cuando lo que se invoca como título es una relación de familia. ¿Se desprotege la propiedad?, en Estudios de derecho civil XII (Santiago, Thomson Reuters, 2017). Sin embargo, hay autores que, para supuestos como éste y sobre la base del art. 915 del Código Civil, sostienen la existencia de una acción restitutoria más general. Si el que construye en suelo ajeno, en cambio, es un mero tenedor, como, por ejemplo, un arrendatario o un usufructuario, se aplicarán las normas previstas para este contrato o relación jurídica, y no el artículo 669. Así lo dice Claro Solar, Luis, cit. (n. 82), p. 220. A su juicio, "Cuando el propietario obra únicamente como tal, reivindicando su predio en virtud de su derecho absoluto de propiedad, la ley lo obliga por motivos de equidad, al indemnizar al edificador, y la misma equidad exige que se distinga entre el poseedor de buena o de mala fe. Cuando obra en virtud de un vínculo jurídico, de una obligación emanada de un contrato o de un cuasicontrato, una agencia oficiosa, por ejemplo, todas las dificultades deben ser resueltas según la naturaleza particular de la obligación existente entre las partes y la equidad no podría ser invocada para modificarlas".
} 
que, por la redacción del artículo pudiera entenderse que el dueño del terreno no se apropia verdaderamente del mismo hasta que no pague las indemnizaciones. Tal condicionamiento, pues, no tiene otra función que la de asegurar el pago; la misma que tenía en las fuentes romanas la exceptio doli que oponía el demandando en la reivindicatoria. En definitiva, en virtud del principio superficies solo cedit, la cuestión en disputa no es el dominio del edificio, que cede siempre a favor del dueño del suelo, y la opción de h a c e r s u y o el edificio se traduce en el ejercicio de la acción reivindicatoria para recuperar la posesión del terreno ${ }^{90}$.

Y así, el propietario del suelo (y dueño del edificio por accesión) deberá efectuar "las indemnizaciones prescritas a favor de los poseedores de buena o mala fe en el título De la reivindicación [...]"91. Si el poseedor está de buena fe y es vencido, debe restituir (el suelo con el edificio adherido), pudiendo exigir el valor del edificio, que tiene consideración de mejora útil. Si estaba de mala fe, en cambio, debe restituir, pero no tendrá derecho a indemnización alguna. Se le permite, en todo caso, separar los materiales -ius tollendi- siempre que dicha separación no perjudique la integridad de la edificación ${ }^{92}$. La fuente de esta parte de la norma, que distingue entre constructor de buena o mala fe parece ser el texto de Justiniano al que nos referimos (Inst. 2, 1,30).

La segunda parte del inc. $1^{\circ}$ señala que el dueño del suelo puede obligar al poseedor vencido a comprarle el terreno. A mi juicio, por la misma fuerza del principio superficies solo cedit, la adquisición dominical del edificio se produce, también en este caso, derechamente por accesión. De este modo, el dueño del suelo lo es también del edificio, antes y después de ejercer el derecho de opción ${ }^{93}$, y, en

${ }^{90}$ Una opinión distinta puede verse, entre otros, en Ramos, René, Edificación en sitio ajeno sin previo contrato (en torno al artículo 669 del Código Civil), en Revista de Derecho Universidad de Concepción, 178 (julio-diciembre, 1985), pp. 141 ss. La accesión, a su juicio, no se consuma hasta el pago del valor de la edificación por parte del dueño del terreno. En el mismo sentido argumenta Domínguez Á., Ramón, Precario. Construcción en suelo ajeno, en Revista de Derecho Universidad de Concepción, 198 (julio-diciembre, 1995), p. 192: mientras no se acredite el pago de las indemnizaciones, hay dos derechos de dominio que coexisten. En un sentido similar, WAHL, Jorge, El principio de lo accesorio y las convenciones en materia de edificación y plantación, en Estudios de Derecho Civil III (Valparaíso, Legal Publishing, 2007), pp. 317 y ss. Me sumo a los argumentos que aduce GonZÁLEZ, Manuel, cit. (n. 81), pp. 247 ss. que, con abundante y pertinente bibliografía, apoya la tesis de la accesión automática. En efecto, dicha doctrina es más coherente con la naturaleza de la accesión y con el principio superficies solo cedit.

${ }^{91}$ Atria' Fernando, Adquisición de derechos reales, accesión de mueble a inmueble, en Revista de Derecho de la Universidad Adolfo Ibáñez, Comentario de la jurisprudencia del año 2003, 1 (Peñalolén-Viña del Mar, 2004), p. 22 señala, en cambio, que la finalidad del artículo 669 es tan solo determinar si el dueño toleró o no la construcción, prescindiendo del tipo de mejora hecha en el inmueble. En otras palabras, el artículo no diría relación con las reglas sobre prestaciones mutuas de la acción reivindicatoria.

${ }^{92}$ Lo dice el artículo 910 del Código Civil: puede retirar los materiales siempre que pueda separarlos sin detrimento de la cosa reivindicada, y que el propietario rehúse pagarle el precio que tendrian dichos materiales después de separados. La norma es aplicable dado que el propio art. 669 se remite a las disposiciones referidas a la acción reivindicatoria.

${ }^{93} \mathrm{La}$ ley no indica expresamente cuándo se ejerce esta opción. Teniendo en cuenta que la liquidación de las prestaciones mutuas se hará normalmente en la fase de ejecución de la sentencia, la opción se hará probablemente con anterioridad a la interposición de la demanda 
consecuencia, si decide obligar al poseedor a comprar el terreno, y este accede, deberá hacer la tradición del mismo ${ }^{94}$.

Cuando la construcción fue hecha a ciencia y paciencia del dueño del suelo -inciso $2^{\circ}$ del artículo $669^{95}$-, solo podrá éste recuperar el predio si paga el valor del edificio ${ }^{96}$. Si no está dispuesto a pagarlo, perderá el dominio del terreno y edificio adherido (que había ganado por accesión), que pasará al constructor por disposición de la misma norma.

Por otra parte, el inciso $2^{\circ}$ no distingue en qué disposición anímica se encuentra el constructor, de forma que debe ser indemnizado por el dueño del suelo, aun cuando esté de mala fe, esto es cuando sabe que el suelo en que construye es ajeno. Si la construcción no hubiera sido conocida por el dueño del suelo, en cambio, este constructor de mala fe, en aplicación del inciso $1^{\circ}$ del art. 669, no podría reclamar nada.

Tampoco se preocupa el legislador de calificar la disposición sicológica del dueño del terreno; parece que bastaría con la anuencia para quedar obligado a indemnizar.

No lo piensa así Claro Solar: inspirándose en el proyecto de García Goyena, afirma que el dueño del terreno ha procedido de mala $\mathrm{fe}^{97}$; no detuvo las obras

reivindicatoria. En efecto, al tratarse de dos juicios con objetivos completamente distintos e incluso contrapuestos, no cabría ejercer el derecho de opción en el marco de la misma acción reivindicatoria, ni siquiera en su fase declarativa. Si ha ejercido la reivindicatoria, ha optado por hacer suyo el edificio. Si opta por dejar de lado la reivindicatoria y obligar al constructor a comprar, intentará llegar a un acuerdo contractual; en el caso de que fuera inviable, no debe descartarse una demanda contra el poseedor para obligarlo a celebrar el contrato. Si el constructor se niega a comprar el terreno estaría incumpliendo una obligación que le impone la ley, y, en consecuencia, podrá iniciarse un juicio relativo a esta obligación de comprar. Si resulta vencido, será condenado a otorgar contrato, y, si permanece en su negativa, habrá que recurrir a un cumplimento forzado de la obligación, en cuyo caso podrá aplicarse lo dispuesto en el art. 532 del Código de Procedimiento Civil. "Si el hecho debido consiste en la suscripción de un instrumento o en la constitución de una obligación por parte del deudor, podrá proceder a su nombre el juez que conozca del litigio, si, requerido aquél, no lo hace dentro del plazo que le señale el tribunal'.

${ }^{94}$ Que sería, en este caso, una traditio brevi manu: el constructor ya tenía la cosa (el terreno) en su poder.

${ }^{95}$ En relación con las fuentes inspiradoras del inciso $2^{\circ}$ del artículo hay muy poca seguridad. Puede verse a este respecto, GonZÁlEZ, Manuel, cit. (n. 81), pp. 226 y ss., 262, nº 1, quien sostiene que Bello pudo haberse inspirado, o bien en el ABGB austríaco (1811) o bien en el proyecto de García Goyena. Afirma que este inciso es completamente original por cuanto prescinde de la buena o mala fe del constructor: debe ser indemnizado en todo caso.

${ }^{96}$ SCHIEle, Carolina, La edificación en suelo ajeno: el problemático inciso $2^{\circ}$ del artículo 669 del Código Civil. El Mercurio Legal. Disponible en http://www.elmercurio.com/legal/noticias/ opinión/2017/09/27/la edificacion-en-suelo-ajeno-el-problematico-inciso-2-del-artticulo-2del-codigo-civil.aspx. (Fecha de consulta: 4 de noviembre de 2017), comenta algunos fallos en que se establece que las construcciones acceden al suelo, independientemente del pago de las indemnizaciones (se refiere a una sentencia reciente de la Corte de Apelaciones de Concepción), mientras otros condicionan la adquisición del dominio del suelo a este pago. A su juicio, "resulta necesario revisar, una vez más, el contenido del artículo 669 del Código Civil”.

${ }^{97}$ En ese sentido, Claro Solar, Luis (n. 82), pp. 239 ss. Es la solución del artículo 364 del Código Civil español (procedente del proyecto de García Goyena) que entiende mala fe por parte del dueño cuando el hecho "se hubiere ejecutado a su vista, ciencia y paciencia, sin oponerse". 
porque lo movía el afán de lucrarse con la obra, con la esperanza de que la indemnización pueda ser inferior a la ganancia que le suponía la construcción acabada. Así, la mala fe del edificador se compensa con la mala fe del propietario, el cual debe indemnizar al primero como si se tratara de un poseedor de buena $\mathrm{fe}^{98}$.

Otra interpretación consiste en afirmar que si el dueño del terreno no ha detenido las obras, es porque hay un consentimiento implícito entre las partes. Según González ${ }^{99}$, y en contra de esta tendencia doctrinal, no puede hablarse de una relación contractual, ni siquiera implícita: no hay consentimiento cuando solo puede suponerse la aceptación de una de las partes del contrato. Su argumentación, de mucho peso, se resume esencialmente en que se trata de un enriquecimiento no impuesto (precisamente por la aquiescencia del dueño del suelo), que lo obliga a indemnizar.

Puede añadirse, por otra parte, que si la aquiescencia fuese entendida como aceptación de una construcción proyectada por el edificador, habrá que probar que el dueño del suelo ha manifestado su consentimiento en este sentido. Pero, si se comprueba dicha aceptación, ya no se aplicará esta norma, sino las reglas de la figura contractual específica (contrato de construcción como modalidad de arrendamiento de obra).

En definitiva, en el inciso no consta de ningún modo que haya un ánimo de contratar, ni a título gratuito (donación ${ }^{100}$ ), ni a título oneroso (si se presume un contrato de construcción). Tampoco puede presumirse la mala fe del dueño del suelo que toleró la construcción; mala fe que, al menos en el contexto de esta norma, parece irrelevante.

Así, pues, aunque el referido inciso no menciona cuál es la actitud sicológica del dueño del terreno, tras un descarte de las diversas posibilidades planteadas, podemos decir: o bien se trata de un dueño que de mala fe toleró la construcción con intención de lucrarse de la mejora, o bien se trata de un dueño que no detuvo la obra por mera negligencia. En uno o en otro caso (mala fe o negligencia) deberá pagar las mejoras para recuperar el predio.

\section{Conclusiones}

1. En virtud del principio de origen antiguo superficies solo cedit, tanto en el caso de construcción con materiales ajenos en suelo propio como en el de edificación en suelo de otro, el edificio se hace del dueño del suelo por accesión. El principio

${ }^{98}$ La buena o mala fe del constructor está considerada desde la perspectiva de la posesión y gira solo en torno al conocimiento o no de la ajenidad del terreno. La mala fe del dueño del terreno, en cambio, se refiere a una maquinación fraudulenta que le permitirá enriquecerse con la construcción levantada en su terreno. Habría que preguntarse si la compensación entre una mala fe y otra es procedente.

${ }^{99}$ GonZÁlez, Manuel, cit. (n. 81), pp. 247 ss.

${ }^{100}$ Se trata de la dificultad que ya planteaba la interpretación del texto mencionado en n. 62 en que el emperador comentaba este supuesto; el que edifica de buena fe no puede tener animus donandi, precisamente porque no sabe que el suelo es ajeno. Debe excluirse, por tanto, que el dueño del suelo esté aceptando, con su anuencia, una donación del edificio levantado por el constructor; al ser una donación nunca será reclamado como mejora. 
rige con todo su vigor en los dos artículos del Código Civil chileno que regulan esta materia (668 y 669).

2. La prohibición de separar los materiales incorporados -de origen decenviralse aplica tanto a la construcción con materiales ajenos en suelo propio como a la edificación en suelo de un tercero, aunque con alcances distintos en uno y otro caso, y se mantiene, aunque no enunciada de modo explícito, en los dos artículos mencionados del Código Civil chileno.

3. En el primer supuesto, el derecho romano, en compensación a esa prohibición, concede al dueño de los materiales una actio de tigno iuncto, con carácter penal, por el doble del valor de los materiales, que procede cuando ha habido hurto de los materiales. No parece plausible que la acción proceda también en los casos de tignum alienum (materiales apropiados de buena fe). La colocación edictal de la acción (en el título De Furtis); la condena al doble; y la cumulatividad con la acción reivindicatoria, hacen pensar que se trata de un tipo especial de hurto.

4. A pesar de la existencia de esa prohibición antigua, en el primer supuesto los juristas proculeyanos admiten el ius tollendi cuando el edificio aún está en pie, de modo que no puede hablarse de una pérdida absoluta de los materiales; y una posterior acción reivindicatoria en caso de que el edificio pierda su integridad, compatible con la penal actio de tigno iuncto. Por efecto de la legislación posclásica justinianea, el dueño de los materiales pierde el dominio sobre ellos al quedar incorporados al edificio, y, en consecuencia, desaparece la acción reivindicatoria posterior a la destrucción del mismo, decisión que recoge el artículo 668 del Código Civil chileno.

5. La actio de tigno iuncto desaparece en las legislaciones modernas; en virtud del desarrollo posclásico, y en especial justinianeo, ella es sustituida por una acción por el valor de los materiales, tal como señala el artículo 668 del Código Civil chileno. La norma, a nuestro juicio, deriva directamente de este desarrollo posclásico, a través de García Goyena. A ella puede añadirse, según agrega la misma disposición, una indemnización de perjuicios por error inmotivado, $y$, eventualmente, una acción criminal, en caso de hurto, robo o estafa.

6. En el segundo supuesto -la edificación en suelo de un tercero- se plantea en derecho romano un problema posesorio, que se resuelve a través de la concesión de la acción reivindicatoria al dueño del suelo, y de la exceptio doli al poseedor de buena fe para exigir el reembolso de las mejoras.

7. Si se ha edificado en el suelo de uno que es pobre, el derecho romano clásico lo libera de pagar las mejoras, aunque puede autorizar al poseedor vencido a que retire los objetos cuya separación no cause detrimento en la edificación. De esta forma puede deducirse que tampoco en este segundo supuesto se produce una pérdida total y definitiva de los materiales incorporados en una construcción (época clásica).

8. El artículo 669 del Código Civil chileno, frente al problema posesorio que genera la construcción en suelo ajeno, concede al dueño del suelo - al igual que en las fuentes romanas- la acción reivindicatoria, y al poseedor de buena fe las indemnizaciones prescritas en su favor (obtenidas en la antigüedad a través de la exceptio doli). La novedad, que parece originarse en García Goyena, es la alternativa 
que ofrece al dueño del predio: obligar al poseedor a comprarle el terreno. Vemos que la solución, es, de algún modo, equivalente a la presentada por Celso para el caso de ser pobre el propietario del suelo.

Dicha opción desaparece en el inciso segundo del artículo. El dueño que toleró la construcción levantada por otro de buena fe, deberá pagar en todo caso la mejora, no siendo relevante la actitud sicológica que haya tenido (con ánimo de lucro o por mera negligencia). No deberá presumirse, tampoco, en esa aquiescencia, un ánimo de contratar, ni a título gratuito ni a título oneroso.

\section{BiBLIOGRAFÍA CITADA}

ATRIA, Fernando, Adquisición de derechos reales, accesión de mueble a inmueble, en Revista de Derecho de la Universidad Adolfo Ibánez. Comentario de la jurisprudencia del año 2003, 1 (Peñalolén-Viña del Mar, Universidad Adolfo Ibáñez, 2004), pp. 21-32. Bello, Andrés, Instituciones de derecho romano (Santiago de Chile, Libr. Central de Augusto Raymond, Impr. Nacional, 1871).

Biond, Biondo, Istituzioni di diritto romano (reimp. de la 4 a ed., Milán, Giuffrè, 1972). BlánqueZ, Agustín Diccionario Latino-Español, (5ª ed., Barcelona, editorial Ramón Sopena, 1982).

Buckiand, William, A Manual of Roman Private Law (Cambridge, University Press, 2011).

BÜRGE, Alfons, Retentio im römischen Sachen-und Obligationenrecht (Zürich, Schulthess Polygrapischer Verlag, 1979).

Claro Solar, Luis, Explicaciones de derecho civil chileno y comparado (Santiago, Editorial Jurídica de Chile, 2013).

Corbino, Alessandro, Inosservanza di doveri privati in etá decenvirale, en CAPOGROsSI Colognesi, Luigi y Cursi, Maria Floriana (eds.), Forme di responsabilitá in etá decenvirale, (Napoli, Jovene, 2008), pp. 21-39.

De Marini, Franca, Recensión a Quadrato, Tignum Iunctum, en Labeo, 15 (1969) pp. 378-381.

Domínguez Á., Ramón (1995), Precario. Construcción en suelo ajeno, en Revista de Derecho Universidad de Concepción, 198 (julio-diciembre 1995), pp. 189-193.

D'Ors, Álvaro, Derecho privado romano (9a ed., Pamplona, Eunsa, 1997).

EnNeCerus, Kipp, WolfF, Tratado de derecho civil, derecho de cosas (8a ed., traducción de la $32^{\mathrm{a}}$ ed. alemana con estudios de comparación y adaptación a la legislación y jurisprudencia española por Blas Pérez y José Alguer, Barcelona, Bosch, 1936).

ETCHEBERRY, Leonor, El título en el precario: análisis jurisprudencial cuando lo que se invoca como titulo es una relación de familia. ¿Se desprotege la propiedad?, en Estudios de derecho civil XII, (Santiago, Thomson Reuters, 2017), pp. 73-86.

García Goyena, Florencio, Concordancias, motivos y comentarios del Código Civil Español (Madrid, Imprenta de la Sociedad Tipográfico- Editorial, 1852).

GIRARD, Paul, Manuel elementaire de droit romain (8a ed., París, 1929).

Guarino, Antonio, Diritto privato romano (11 a ed., Napoli, Jovene, 1997).

Guarneri Citati, Andrea, La cosidetta accessione separabile e $i$ suoi effeti, en Annali Palermo, 14 (1930), 227-387.

GonzÁlez, Manuel, Construcción en suelo ajeno a ciencia y paciencia del dueño del terreno: una aproximación dogmática al inciso segundo del artículo 669 del Código Civil, en Revista Chilena de Derecho Privado, 28 (Santiago, 2017), pp. 221-269. 
GuZmán Brito, Alejandro, Derecho privado romano (2a ed., Santiago, LegalPublishing Thompson Reuters, 2013).

- Andrés Bello Codificador (Santiago, Editorial Universitaria, 1982).

Hincker, Hannes, Tignum Iunctum, en SZZ., 121 (1991), pp. 94-122.

IGLESIAS, Juan, Derecho romano (17a ed., Barcelona, Ariel, 2008).

KASER, Max, Typisierter "dolus" im altrömischen Recht, en BIDR., 65 (1962), pp. 79-104.

— Recensión a Melillo, Tignum Iunctum, en Labeo, 12 (1966), pp. 104-111.

- Derecho romano privado (trad. cast. de la 5a ed., 2a ed., Madrid, Reus, 1982).

LeITAO, Francisca, La formación histórica del modo de adquirir denominado "accesión", en Revista de Estudios Histórico-Jurídicos, 39 (2008), pp. 61-117.

Lemosse, Maxime, Recensión a Melillo, Tignum Iunctum, en RHD., (1966), pp. 88-90.

Lira Urquieta, Pedro, El Código Civil chileno y su época (Santiago, Editorial Jurídica de Chile, 1956).

Marrone, Matteo, "Tignum iunctum" e "Inaedificatio", en Labeo, 37 (1991), pp. 382-388.

Mayer-Maly, Theodor, Recensión a Melillo, Tignum Iunctum, en SDHI., 33 (1967), pp. 433-438.

Medicus, Dieter, Recensión a Melillo, Tignum Iunctum, en SZZ., 97 (1967), pp. 476-481.

Melillo, Generoso, Tignum Iunctum (Napoli, Giuffrè, 1964).

MeInCKe, Jens Peter, Superficies solo cedit, en SZZ., 88 (1971), pp. 136-183.

Monier, Le tignum iunctum (Paris, Recueil Sirey, 1922).

Musumeci, Francesco, Vicenda storica del "Tignum Iunctum", en BIDR., 89 (1978), pp. 201-265.

- Inaedificatio (Milano, Giuffrè, 1988).

Pampaloni, Muzio, Studi sopra il delitto di furto, en BIDR., 21 (1909), pp. 203-221.

PASQUINO, Paola, Rimedi pretori in alcuni casi di accessione, en TSDP., 4 (2011), pp. 1-105.

Ramos, René, Edificación en sitio ajeno sin previo contrato (en torno al artículo 669 del Código Civil), en Revista de Derecho Universidad de Concepción, 178 (juliodiciembre 1985), pp. 141-147.

Rascón, César y García, José María, Ley de las Doce Tablas (Madrid, Tecnos, 2011). Riccobono, Salvatore, Studi critici sulle fonti del diritto romano, en BIDR., 8 (1895). Rodríguez EnNEs, Luis, La obra de García Goyena y el proceso codificador iberoamericano, disponible en www.uni7.edu.br/periódicos/index.php/revistajuridica/article/ download/199/222. (Fecha de consulta: 20 de octubre de 2018), pp. 29-48.

Ruiz Castellanos, Antonio, Ley de la Doce Tablas (Madrid, Ediciones Clásicas, 1992).

Salinas, Carlos, Notas en torno a las actas de los proyectos del "Código Civil" chileno, en rdpucv.cl/index.php/rderecho/article/viewFile/2/2. (Fecha de consulta: $10 \mathrm{de}$ junio de 2019), pp. 33-41.

SAN MARTín, Lilian, Algunas consideraciones sobre el contrato para la confección de obra material. Problemas derivados de su configuración típica, en Estudios de derecho civil X, (Santiago, Thomson Reuters, 2015), pp. 751-771.

- Contrato para la confección de obra material. Naturaleza jurídica y otros problemas dogmáticos, en Revista de Derecho Universidad Católica del Norte, 23/2 (2016), pp. 145-179. 
SCHIELE, Carolina, La edificación en suelo ajeno: el problemático inciso $2^{\circ}$ del artículo 669 del Código Civil. El Mercurio Legal. Disponible en http://www.elmercurio.com/ legal/noticias/opinión/2017/09/27/la edificacion-en-suelo-ajeno-el-problematicoinciso-2-del-articulo-2-del-codigo-civil.aspx. (Fecha de consulta: 4 de noviembre de 2017).

Schulz, Fritz, Derecho clásico romano (trad. cast., Barcelona, Bosch, 1960).

Soza, María de los Ángeles, La edificación y la adquisición del dominio del edificio, en Estudios de Derecho Civil V, Jornadas Nacionales de derecho civil, (Concepción, Abeledo Perrot, LegalPublishing, 2009), pp. 165-179.

Talamanca, Mario, Istituzioni di diritto romano (Milán, Giuffrè, 1990), p. 419.

- Delitti e pena privata nelle XII Tavole, en Capogrossi Colognesi, Luigi y Cursi, Maria Floriana (eds.), Forme di responsabilitá in etá decenvirale, (Napoli, Jovene, 2008), pp. 41-100.

VocI, Pasquale, Istituzioni di diritto romano (Milano, Giuffrè, 1996).

Volterra, Eduardo, Instituciones de derecho privado romano (trad. cast., Madrid, Civitas, 1986).

WAHL, Jorge, El principio de lo accesorio y las convenciones en materia de edificación y plantación, en Estudios de derecho civil III, (Valparaíso, Legal Publishing, 2007), pp. 315-324.

WaTsOn, Alan, Tignum Iunctum, the XII Tables and a Lost Word, en RIDA., 21 (1974), pp. 337-342.

ZAERA, Ana, Superficies solo cedit, en Anuario da Facultade de Dereito da Universidade da Coruña, 12 (2008), pp. 1107-1118.

- La propiedad superficiaria en el derecho romano justinianeo, en RIDA., 51 (2004), pp. 369-382. 